\title{
Formaldehyde and nitrogen dioxide over the remote western Pacific Ocean: SCIAMACHY and GOME-2 validation using ship-based MAX-DOAS observations
}

\author{
E. Peters ${ }^{1}$, F. Wittrock ${ }^{1}$, K. Großmann ${ }^{2}$, U. Frieß ${ }^{2}$, A. Richter ${ }^{1}$, and J. P. Burrows ${ }^{1}$ \\ ${ }^{1}$ Institute of Environmental Physics (IUP), University of Bremen, Otto-Hahn-Allee 1, 28359 Bremen, Germany \\ ${ }^{2}$ Institute of Environmental Physics (IUP), University of Heidelberg, Im Neuenheimer Feld 229, 69120 Heidelberg, Germany \\ Correspondence to: E. Peters (enno.peters@iup.physik.uni-bremen.de)
}

Received: 4 June 2012 - Published in Atmos. Chem. Phys. Discuss.: 28 June 2012

Revised: 18 October 2012 - Accepted: 5 November 2012 - Published: 27 November 2012

\begin{abstract}
In October 2009, shipborne Multi-Axis Differential Optical Absorption Spectroscopy (MAX-DOAS) measurements were performed during the TransBrom campaign over the western Pacific Ocean $\left(\approx 40^{\circ} \mathrm{N}\right.$ to $\left.20^{\circ} \mathrm{S}\right)$. Vertical tropospheric trace gas columns and profiles of nitrogen dioxide $\left(\mathrm{NO}_{2}\right)$ and formaldehyde $(\mathrm{HCHO})$ as well as stratospheric $\mathrm{NO}_{2}$ columns were retrieved in order to validate corresponding measurements from the GOME-2 and SCIAMACHY satellite instruments and to estimate tropospheric background concentrations of these trace gases.

All instruments reproduced the same characteristic, latitude-dependent shape of stratospheric $\mathrm{NO}_{2}$. SCIAMACHY and GOME-2 data differ by about $1 \%$ from each other while yielding lower vertical columns than MAXDOAS morning values as a consequence of measurement time and stratospheric $\mathrm{NO}_{2}$ diurnal cycle. Due to this diurnal cycle, an increase of $8.7 \pm 0.5 \times 10^{13}$ molec cm $^{-2} \mathrm{~h}^{-1}$ of stratospheric $\mathrm{NO}_{2}$ was estimated from MAX-DOAS data at low latitudes during the day.

Tropospheric $\mathrm{NO}_{2}$ was above the detection limit only in regions of higher anthropogenic impact (ship traffic, transport of pollution from land). A background column of $1.3 \times 10^{14} \mathrm{molec}^{-2}$ (or roughly $50 \mathrm{ppt}$ boundary layer concentration) can be estimated as upper limit for the remote ocean, which is in agreement with GOME-2 monthly mean values. In the marine boundary layer close to the islands of Hokkaido and Honshu, up to $0.8 \mathrm{ppbv}$ were retrieved close to the surface.

Background HCHO concentrations over the remote ocean exhibit a diurnal cycle with maximum values (depending
\end{abstract}

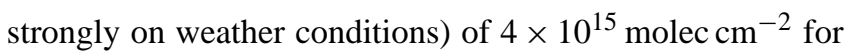
the vertical column at noontime. Corresponding peak concentrations of up to $1.1 \mathrm{ppbv}$ were retrieved in elevated altitudes $(\approx 400 \mathrm{~m})$ around noon while maximum concentrations in the evening are close to the ground. An agreement between MAX-DOAS and GOME-2 data was found for typical vertical columns of $3 \times 10^{15}$ molec cm $\mathrm{cm}^{-2}$ over the remote ocean at the time of overpass.

\section{Introduction}

Nitrogen dioxide $\left(\mathrm{NO}_{2}\right)$ and formaldehyde $(\mathrm{HCHO})$ are important trace gases in the atmosphere. They can be detected by remote sensing techniques due to their characteristic absorption features in the visible and the UV spectral range, respectively.

The nitrogen oxides $\mathrm{NO}$ and $\mathrm{NO}_{2}\left(\mathrm{NO}+\mathrm{NO}_{2}=\mathrm{NO}_{\mathrm{x}}\right)$ are prominent pollutants in the troposphere, powerful oxidants, key ingredients in the formation of tropospheric ozone and harmful for lung tissue. They are produced predominantly at high temperatures in combustion processes, both anthropogenic (burning of fossil fuel in industry, power generation and traffic) and biogenic (bush and forest fires), as well as in soil microbial processes and lightning events (Lee et al., 1997). As a consequence, $\mathrm{NO}_{2}$ is detected above industrialized and urban areas, traffic routes and over bush fires (e.g. Richter and Burrows, 2002; Richter et al., 2004; Franke et al., 2009; Konovalov et al., 2010). In higher concentrations, $\mathrm{NO}_{2}$ can be observed even by eye as it causes the typical brownish 
color of polluted air and exhaust plumes. Sinks for $\mathrm{NO}_{2}$ are the reaction with the hydroxyl radical $\mathrm{OH}$ and photolysis. The former reaction produces nitrous acid $\left(\mathrm{HNO}_{3}\right)$, leading to acidification of precipitation and thereby of soil and water. Photolysis of $\mathrm{NO}_{2}$ produces ozone and $\mathrm{NO}$, which can react again with ozone to form $\mathrm{NO}_{2}$. Thus, in the absence of peroxide radicals (e.g. in a remote, clean environment) an equilibrium between $\mathrm{NO}, \mathrm{NO}_{2}$ and ozone would develop as a function of sunlight intensity.

In the stratosphere, the nitrogen oxides $\mathrm{NO}$ and $\mathrm{NO}_{2}$ are key species in catalytic cycles leading to ozone depletion (Crutzen, 1970; Johnston, 1971). They are transported upwards from the troposphere in form of the long-lived nitrous oxide $\left(\mathrm{N}_{2} \mathrm{O}\right)$, originating from microbiological activity in soil (Bates and Hays, 1967) as well as from anthropogenic sources (e.g. traffic). Reaction of $\mathrm{N}_{2} \mathrm{O}$ with excited oxygen atoms in the stratosphere, produced mainly by UV photolysis of ozone, yields then nitrogen monoxide (Brasseur et al., 1999), which is subsequently converted to $\mathrm{NO}_{2}$.

Formaldehyde (HCHO) is the simplest and most abundant aldehyde in the atmosphere belonging to the huge family of oxygenated volatile organic compounds (OVOCs). It is produced during photochemical degradation of methane $\left(\mathrm{CH}_{4}\right)$ and non-methane hydrocarbons (NMHC). The oxidation of methane produces a global HCHO background with reported surface levels of $0.2-1 \mathrm{ppbv}$ in remote marine environments (Weller et al., 2000; Singh et al., 2001; Burkert et al., 2001). In addition, $\mathrm{HCHO}$ originates from biomass burning and fossil fuel combustion (Anderson et al., 1996) and vegetation (Seco et al., 2006). The major sinks of HCHO are photolysis at wavelengths below $400 \mathrm{~nm}$, reaction with $\mathrm{OH}$ and wet deposition, resulting in a short lifetime of a few hours (Arlander et al., 1995). As a consequence, elevated HCHO levels are found close to its sources, over rainforests, bush fires or shipping routes (e.g. Marbach et al., 2009; Stavrakou et al., 2009).

$\mathrm{NO}_{2}$ and $\mathrm{HCHO}$ have been observed from space for many years (e.g. Richter et al., 2005; Leue et al., 2001; Martin et al., 2002; Wittrock et al., 2000; Palmer et al., 2003; De Smedt et al., 2008) by means of the well-known DOAS technique (Platt, 1994) using backscattered sunlight from Earth. Satellite instruments provide a global image of $\mathrm{NO}_{2}$, $\mathrm{HCHO}$ and other trace gas distributions and allow to detect and observe source regions of high concentrations (e.g. Richter et al., 2004, 2005; Wittrock et al., 2006; Marbach et al., 2009; Stavrakou et al., 2009). Nevertheless, these instruments have problems detecting trace gases over remote oceanic regions, as concentrations in the troposphere there are usually under instrumental detection limits. Thus, the accuracy of these measurements is unclear. In addition, the low albedo of the ocean's surface, as well as spectral structures introduced by liquid water absorption and vibrational Raman scattering in water-leaving radiance, limits the accuracy of satellite measurements (Vountas et al., 2003). On the other hand, independent remote sensing ground-based mea- surements for validation of satellite measurements of $\mathrm{NO}_{2}$ and $\mathrm{HCHO}$ in marine regions are rare, as they have been performed predominantly over land (e.g. Wittrock et al., 2006; Irie et al., 2008) and so far shipborne MAX-DOAS measurements have been focused on other trace gases (e.g. Martin et al., 2009; Sinreich et al., 2010) or were not aiming at validating satellite measurements (e.g. Takashima et al., 2011).

Objectives of this study are to (i) estimate background columns of tropospheric $\mathrm{HCHO}$ and $\mathrm{NO}_{2}$ in a remote marine environment as well as stratospheric $\mathrm{NO}_{2}$ columns and their latitudinal distribution and (ii) validate satellite measurements of the SCIAMACHY and GOME-2 instruments with independent ground-based MAX-DOAS measurements. These measurements were performed during the TransBrom cruise in October 2009 (Krüger and Quack, 2012) in the western Pacific region. A MAX-DOAS instrument uses a similar measurement technique as satellite DOAS-instruments, but due to the viewing geometry, a much longer light path in the lower troposphere can be achieved. Therefore a MAX-DOAS instrument is more sensitive for tropospheric absorbers and allows estimating tropospheric trace gas columns and concentrations in a remote environment with better accuracy. Thus, it is applicable for the validation of satellite instruments.

The following Sect. 2 gives an overview about the TransBrom campaign. In Sect. 3, the different instruments and the data analysis used in this study are described. Measurement results of stratospheric and tropospheric $\mathrm{NO}_{2}$ as well as $\mathrm{HCHO}$ are presented in Sect. 4.

\section{The TransBrom campaign}

The TransBrom campaign was carried out onboard the German research vessel Sonne departing from Tomakomai, Japan $\left(42^{\circ} 38^{\prime} \mathrm{N}, 141^{\circ} 37^{\prime} \mathrm{E}\right)$ on 9 October 2009 and arriving in Townsville, Australia $\left(19^{\circ} 15^{\prime} \mathrm{S}, 146^{\circ} 49^{\prime} \mathrm{E}\right)$ on 24 October 2009. The campaign's main objective was to measure bromine compounds in the ocean water and their flux into the atmosphere. The western Pacific region is considered to be the main entrance gate into the stratosphere, where the bromine originating from ocean water could contribute to ozone depletion (Quack, 2010).

One focus of the participation of the IUP Bremen research team and MAX-DOAS instrument was the study of atmospheric bromine monoxide ( $\mathrm{BrO})$, which is not the topic of this manuscript. Here, we focus on trace gas columns of $\mathrm{NO}_{2}$ and $\mathrm{HCHO}$, which were derived simultaneously from the performed MAX-DOAS measurements, in order to validate the spaceborne SCIAMACHY and GOME-2 measurements.

The TransBrom cruise track is shown in Fig. 1a, together with $72 \mathrm{~h}$ backward trajectories calculated with the online model HYSPLIT (Draxler and Rolph, 2011; Rolph, 2011) from the National Oceanic and Atmospheric Administration (NOAA). The trajectories start $10 \mathrm{~km}$ off the ship in 

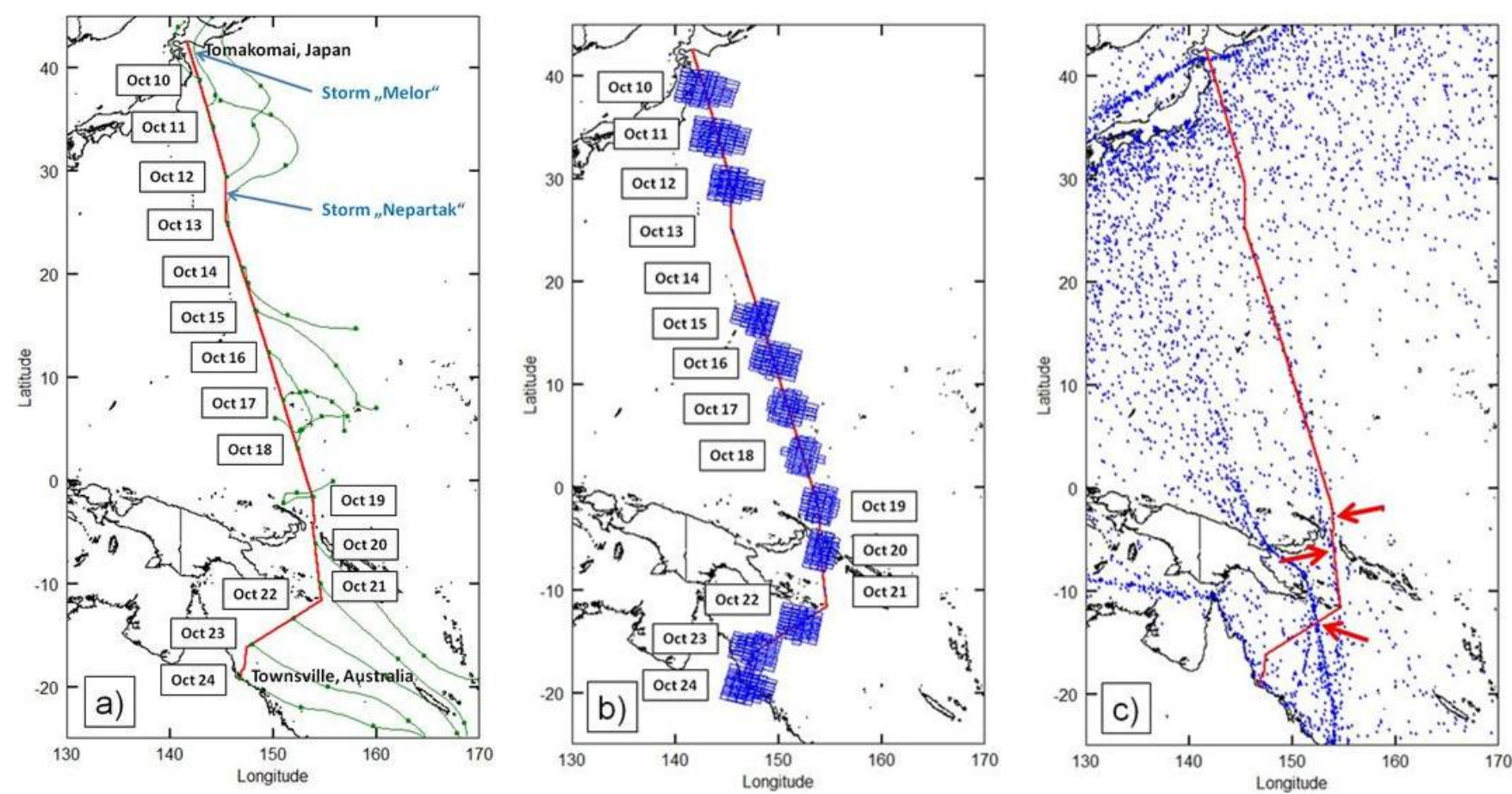

Fig. 1. (a) TransBrom Cruise Track (red) and $72 \mathrm{~h}$ backward trajectories calculated by the NOAA HYSPLIT model (green marks indicate starting point, -1 day, -2 days, -3 days). (b) GOME-2 satellite pixels within a radius of $200 \mathrm{~km}$ around the ship's positions at the time of the overflight. (c) Ship density for 10-24 October 2009 (ship positions reported to the US Coast Guard AMVER System).

Table 1. Prevailing weather and viewing conditions during the TransBrom cruise from 9-24 October 2009.

\begin{tabular}{ll}
\hline Period & Conditions \\
\hline$<10$ October & Storm Melor, delayed departure \\
10 October & Good viewing conditions, almost clear sky \\
$11-12$ October & Increasingly cloudy \\
Night after 12 October & Storm Nepartak, course correction \\
13 October & Heavy rain before noon, clear up in the afternoon \\
14 October & Best viewing conditions, almost clear sky \\
$15-19$ October & Partly cloudy and occasional rain \\
19 October & Backward trajectories reach to the island of New Ireland (closest distance $\approx 150 \mathrm{~km}$ in the evening) \\
$20-22$ October & Almost full cloud cover, occasional rain \\
23 October-end & Improving weather and viewing conditions, sunny \\
\hline
\end{tabular}

the viewing direction of our instrument and at an altitude of $350 \mathrm{~m}$ a.s.1., as this was considered to be a reasonable approximation for the MAX-DOAS probed air at small elevation angles (given an elevation angle of $2^{\circ}$ and a horizontal distance of $10 \mathrm{~km}$, the altitude is $\left.\tan \left(2^{\circ}\right) \times 10 \mathrm{~km} \approx 350 \mathrm{~m}\right)$. As indicated by the calculated backward trajectories, easterly wind directions prevailed throughout the whole campaign. Therefore, the measurements yield typical results for background levels in the remote oceanic troposphere (except for the beginning of the campaign having been influenced from nearby Japanese islands).

The extratropical storm Melor hit Japan shortly before the campaign and our MAX-DOAS instrument could therefore only be set up at sea when wind gusts ceased. 10 October was dominated by good viewing conditions and almost clear sky, 11 and 12 October were increasingly cloudy. A second storm Nepartak with wind speeds of $20 \mathrm{~m} \mathrm{~s}^{-1}$, forced a course correction in the night from 12 to 13 October. From morning to noon of 13 October, it was raining heavily before the ship encountered best viewing conditions and almost clear sky on 14 October. 15-19 October were partly cloudy with occasional rain. Apart from the beginning of the cruise, 19 October was the only event when $72 \mathrm{~h}$ backward trajectories reached to mainland (here: the island of New Ireland). 20-22 October were dominated by an almost full cloud coverage and occasional heavy rains, before the viewing conditions improved 
again towards the end of the cruise. As the backward trajectories in Fig. 1a indicate, strong winds from the open sea prevailed from 20-24 October (during the whole cruise across the Coral sea). The dominating weather conditions during the cruise are summarized in Table 1.

Figure $1 \mathrm{~b}$ shows all measurement pixels from the GOME2 satellite instrument taken within a $200 \mathrm{~km}$ radius around the ship's position at the time of the overflight $(\approx 09: 30 \mathrm{LT})$. For 13, 14 and 21 October, no satellite pixels were available at the corresponding ship's location.

In Fig. 1c, ship positions reported to the US Coast Guard's Automated Mutual-Assistance Vessel Rescue System (AMVER) for the duration of 9-24 October 2009 are displayed, giving an impression of the ship density and preferred shipping routes (D. Horton, US Coast Guard Operations Systems Center, personal communication, 2010). After leaving the polluted region around Japan, the cruise encountered a clean oceanic environment with very limited anthropogenic activities. Red arrows in Fig. 1c indicate locations where tropospheric $\mathrm{NO}_{2}$ events were observed in the MAXDOAS data (Fig. 6).

\section{Instruments and data analysis}

\subsection{The (MAX-)DOAS measurement principle}

For the retrieval of $\mathrm{NO}_{2}$ and $\mathrm{HCHO}$, the well established Differential Optical Absorption Spectroscopy (DOAS) technique is used (Platt and Stutz, 2008). The passive DOAS method is a remote sensing technique using scattered sunlight spectra and is based on the attenuation of light traveling through the atmosphere according to the Lambert-Beer law. The basic idea is to separate the optical thickness (logarithm of the ratio of a measured spectrum to a reference spectrum, which usually is a direct solar spectrum for satellite retrievals and a spectrum in zenith viewing direction for ground-based instruments) in a high-frequency component describing absorption processes by trace gas molecules, and a low-frequency component accounting for scattering and instrumental effects. Trace gas cross sections from laboratory measurements are fitted together with a polynomial accounting for the low-frequency components to the optical thickness yielding so-called (differential) slant column densities (which are often called slant columns (SC), for simplicity) as fit parameters. These have units of molecules per area and represent the respective trace gas concentration integrated over the light path. For ground-based instruments, the retrieved slant columns are not absolute, but the difference between the slant column of the respective measurement and the slant column of the reference measurement. Consequently, to obtain absolute slant columns, the reference slant column has to be known (e.g. from complementary measurements) or estimated (e.g. Langley plot, look-up climatology).
Sensitivity for trace gases at different altitudes depends on the measurement geometry, which is used by groundbased Multi-AXis (MAX)-DOAS measurements (Hönninger et al., 2004; Wittrock et al., 2004). Tropospheric absorbers are measured at elevation angles close to the horizon (the elevation angle is defined as the angle between the horizon and the viewing direction) as the resulting light path in the troposphere is longer then, whereas the sensitivity for stratospheric absorbers is high in zenith viewing direction during twilight due to a long light path through the stratosphere under these conditions.

To convert the obtained slant columns to vertical columns (VC), which represent the respective trace gas concentration integrated over altitude, radiative transfer models (RTM) are used to calculate so-called air mass factors (AMF), the ratio between slant columns and vertical columns (see Sect. 3.5).

\subsection{Satellite instruments}

The Scanning Imaging Absorption spectroMeter for Atmospheric CHartography (SCIAMACHY) instrument is a UVVis-NIR spectrometer onboard the ESA satellite Envisat launched into a sun-synchronous, near-polar orbit in March 2002 measuring backscattered radiation from the Earth's atmosphere or surface (Burrows et al., 1995; Bovensmann et al., 1999). The instrument consists of 8 simultaneously measuring channels, six continuous channels from 214$1750 \mathrm{~nm}$ and two further channels for near-infrared light. The equator crossing time is 10:00 LT, the spatial resolution depends on species and illumination and is typically $60 \times 30 \mathrm{~km}^{2}$ for the data used here. Full coverage at the equator is achieved every six days. SCIAMACHY provided data from August 2002 until April 2012, the end of the Envisat mission.

The Global Ozone Monitoring Experiment-2 (GOME-2) instrument is derived from SCIAMACHY and the GOME instrument, which flew on ERS-2 from 1995 to 2011 (Burrows et al., 1999, and references therein). It is a UV/Vis nadirviewing grating spectrometer on board the MetopA satellite that was launched into a sun-synchronous orbit in October 2006 (Callies et al., 2000). The instrument measures solar radiation scattered and reflected by the atmosphere and covers a wavelength region from $240-790 \mathrm{~nm}$ with a spectral resolution of $0.2-0.4 \mathrm{~nm}$. The equator crossing time is 09:30 LT, the nominal ground-pixel size $40 \times 80 \mathrm{~km}^{2}\left(240 \times 40 \mathrm{~km}^{2}\right.$ for the back scan). Near global coverage is achieved due to a large scan width of $1920 \mathrm{~km}$ every day.

\subsection{Ground-based instrumentation and set-up on the ship}

The IUP Bremen MAX-DOAS instrument comprises a telescope unit which is connected via a split optical fiber bundle with two spectrometers. The telescope unit is mounted on a commercial ENEO VPT-501 Pan-Tilt-Head, which allows 
pointing it in any viewing direction. Light enters the telescope through a fused silica window to avoid cut-off of UV radiation and is focused by a lens on the optical fiber bundle entrance. The telescope's field of view (FOV) is $\approx 1.2^{\circ}$ but may be slightly increased due to the pointing accuracy at sea (see Sect. 3.4). The fiber bundle consists of 76 single fibers and has a length of $20 \mathrm{~m}$. After that it splits into two fiber bundles consisting of 38 single fibers each, leading to two spectrometers, one for the UV and one for the visible spectral range. The fiber bundle arrangement allows separating the light collecting telescope unit from the spectrometers and also overcomes polarization effects. The spectrometers are actively temperature stabilized at $35^{\circ} \mathrm{C}$. The UV spectrometer (ANDOR Shamrock 303i, $12001 \mathrm{~mm}^{-1}$ grating) is equipped with a two-dimensional ANDOR Newton DU940N CCD camera with $512 \times 2048$ pixels. It covers the spectral range of 315-384 nm with an average resolution (FWHM of the slit function) of $0.4 \mathrm{~nm}$. The visible spectrometer is an Acton500 with a two-dimensional ROPER CCD camera with $100 \times 1340$ pixels covering a wavelength interval from 400$570 \mathrm{~nm}$ at a resolution of $0.8 \mathrm{~nm}$.

In addition to the lens-fiber system, the telescope unit contains a video camera for scene documentation and a Mercury/Cadmium ( $\mathrm{HgCd}$ ) line lamp for calibration measurements. Snapshots from the video stream were taken every $5 \mathrm{~s}$ during the whole campaign, providing the possibility to identify events in the trace gas measurement time series (e.g. passing of other ships) as well as viewing condition surveillance (e.g. cloud cover, rain). All measurements and system operations are controlled by in-house software.

The instrument's excellent performance has been demonstrated in the intercomparison campaign CINDI a few months before TransBrom (Roscoe et al., 2010; Piters et al., 2012; Pinardi et al., 2012), where it was selected as one of the reference instruments.

During the cruise, the telescope unit was mounted at the monkey deck above the bridge of the R/V Sonne pointing portside (Fig. 2), which was the western direction for most of the cruise (compare to Fig. 1a). Vertical scans were performed in viewing directions orthogonal to the ship's movement in $1^{\circ}$ steps from $-3^{\circ}$ to $6^{\circ}$ and additionally at $8^{\circ}, 10^{\circ}$, $15^{\circ}$ and $30^{\circ}$ elevation angles. At the end of each scanning sequence, a zenith spectrum was recorded. In off-axis directions (all viewing angles except zenith), the integrated measurement time for each direction was $40 \mathrm{~s}$ consisting of several individual measurements of $100 \mathrm{~ms}$ each. In zenith direction an integration time of $120 \mathrm{~s}$ was applied.

\subsection{Data processing and filtering}

As the ship pitches and tosses in the sea, the elevation angles of the telescope (which are relative to the ship) are not the actual viewing directions. To overcome this effect, spectra were recorded with exposure times of $100 \mathrm{~ms}$. The ship's movements were considered to be negligible within this pe-

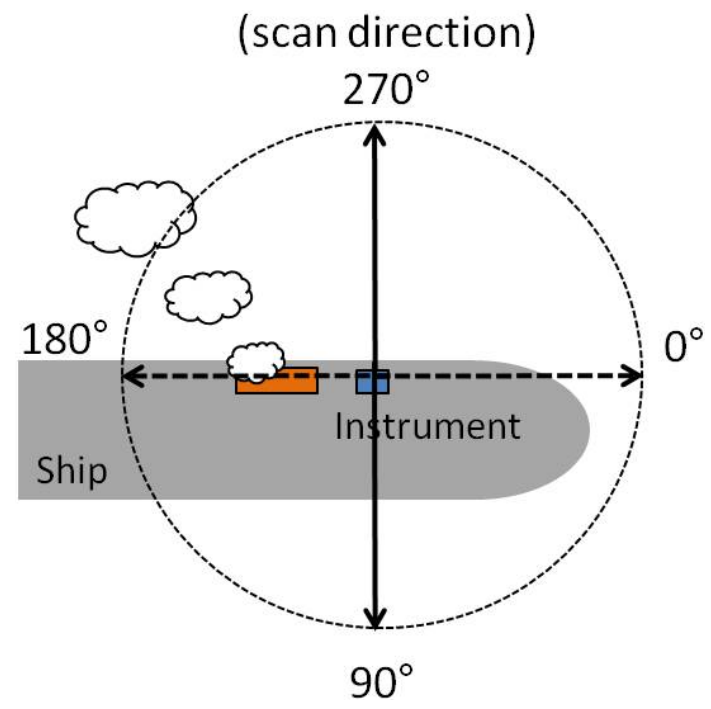

Fig. 2. Schematic bird's eye view of the vessel $\left(0^{\circ}\right.$ is the direction of movement). The grey-shaded area is the ship (seen from above), the orange rectangle is the funnel emitting a plume and the blue box is the MAX-DOAS instrument.

riod. In addition, the ship's heading, pitch and roll angle were recorded every $50 \mathrm{~ms}$ and downloaded from the ship's data base at the end of the cruise. For each vertical scanning sequence, the single $100 \mathrm{~ms}$ measurements were then corrected in terms of the roll angle and sorted according to the real viewing direction with a tolerance of $\pm 0.5^{\circ}$. These corrected individual measurements were then averaged for each viewing angle. As a result, the precision of the viewing direction is $\pm 0.5^{\circ}$, but the time resolution is reduced to the duration of one scanning sequence (typically $10-15 \mathrm{~min}$ ).

In addition, the wind direction was recorded from the ship's weather surveillance systems. To avoid contamination from the ship's exhaust plume, those individual measurements taken under "bad" wind directions (relative wind directions between $80^{\circ}$ and $270^{\circ}$ with respect to the bow, see Fig. 2) were removed before averaging.

\subsection{Data analysis}

For the $\mathrm{NO}_{2}$ retrieval, a fitting window from $450-497 \mathrm{~nm}$ was applied according to Richter (1997). Absorption cross sections of ozone at $223 \mathrm{~K}$ (Bogumil et al., 2003); $\mathrm{NO}_{2}$ (Vandaele et al., 1996) at $294 \mathrm{~K}$ for tropospheric $\mathrm{NO}_{2}$ and at $220 \mathrm{~K}$ for stratospheric $\mathrm{NO}_{2}$, respectively; the oxygen dimer $\mathrm{O}_{4}$ (Hermans et al., unpublished data, http://spectrolab. aeronomie.be/o2.htm); water vapor (HITRAN database, http://www.cfa.harvard.edu/hitran/) as well as a calculated pseudo-cross section accounting for Rotational Raman Scattering (RRS) on air molecules known as the Ring effect (Vountas et al., 1998); a 3rd order polynomial; and an additive offset were considered in the fit. 
For the HCHO retrieval, following the analysis described in Heckel et al. (2005) and detecting tropospheric HCHO with a ground-based MAX-DOAS instrument and the recommendations given in Pinardi et al. (2012), a fitting window from $335-357 \mathrm{~nm}$ was applied. Cross sections of ozone at $223 \mathrm{~K}$ and $273 \mathrm{~K}, \mathrm{NO}_{2}$ at $220 \mathrm{~K}$ (to account for stratospheric contributions), $\mathrm{O}_{4}$ (see references above), $\mathrm{HCHO}$ at $297 \mathrm{~K}$ (Meller and Moortgat, 2000), BrO at $223 \mathrm{~K}$ (Fleischmann et al., 2004) as well as a pseudo-cross section accounting for the Ring effect, a 4th order polynomial and an offset were fitted to the recorded optical depths to retrieve slant columns ${ }^{1}$.

As an example, Fig. 3 shows a tropospheric $\mathrm{NO}_{2}$ DOAS fit (top) and a $\mathrm{HCHO}$ fit (bottom). Stratospheric vertical columns for $\mathrm{NO}_{2}$ were obtained by dividing the slant columns by air mass factors calculated with the radiative transfer model SCIATRAN (Rozanov et al., 2005), version 2.2 during twilight from $88^{\circ}$ to $92^{\circ}$ solar zenith angle (SZA). As input parameters for the radiative transfer model, pressure, temperature and trace gas profiles from the US standard atmosphere were used.

The retrieval of tropospheric vertical columns and/or trace gas profiles from obtained slant columns in different elevation angles is an inverse problem. One method to solve this is the well-known optimal estimation method (Rodgers, 2000). Here, all $\mathrm{NO}_{2}$ and $\mathrm{HCHO}$ tropospheric columns were retrieved using the BRemian Advanced MAX-DOAS Retrieval Algorithm (BREAM) (Wittrock, 2006). BREAM uses a two-step approach. As the light path and therefore the slant columns (especially in viewing directions close to the horizon) depend strongly on the aerosol load, first an aerosol extinction profile is estimated from comparing measured slant columns of the oxygen dimer $\left(\mathrm{O}_{4}\right)$ with $\mathrm{O}_{4}$ slant columns that were simulated with the RTM SCIATRAN for different aerosol extinctions. In this step a correlation factor between measured and simulated $\mathrm{O}_{4}$ slant columns is also calculated to detect cloudy scenes that cannot be corrected for by the applied aerosol extinction profile and the corresponding measurements are removed. In the second step, again using the RTM SCIATRAN, block air mass factors are calculated for the weighting functions describing the relation between the measured slant columns in different elevation angles and the vertical trace gas profile of interest. Then, the optimal estimation is performed using an appropriate a priori trace gas profile. The retrieval grid consists of 80 equally spaced lay-

\footnotetext{
${ }^{1}$ For the analysis of iodine monoxide $(417-439 \mathrm{~nm})$ above the ocean (Großmann et al., 2012), an improvement was achieved by applying a pseudo-cross section accounting for inelastic scattering on molecules in liquid water (Vibrational Raman Scattering, VRS) in the DOAS fit. Its calculation and application in other wavelength regions including the $\mathrm{NO}_{2}$ fitting window used in this study is the subject of current investigation. In the UV, this effect is expected to affect the DOAS fit to a lesser extent as the relative number of photons traveling through liquid water before being scattered in the telescope is lower (as the absorption coefficient of liquid water increases in the UV, see e.g. Raymond and Baker, 1981).
}
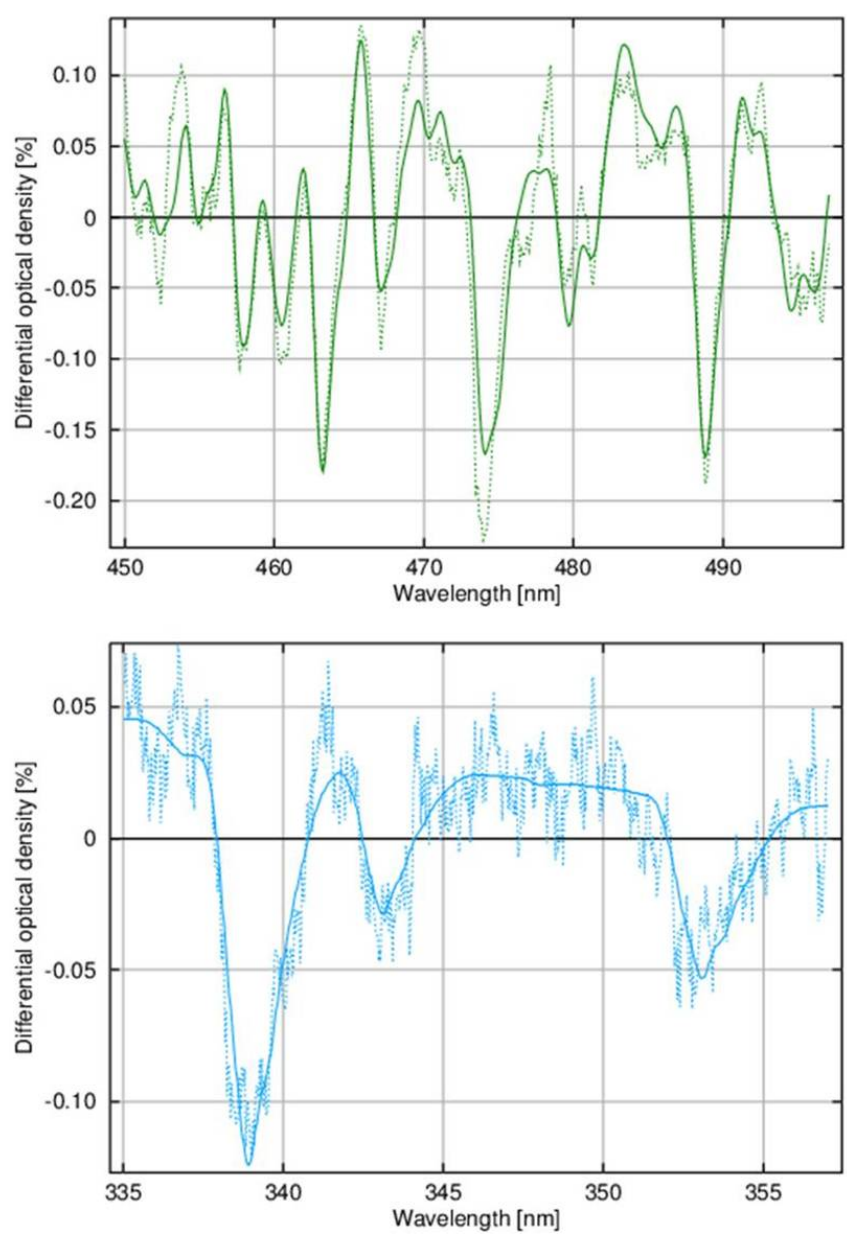

Fig. 3. Example fits for tropospheric $\mathrm{NO}_{2}$ in green (slant column $1.38 \times 10^{16}$ molec cm ${ }^{-2}$, RMS $2.8 \times 10^{-4}$ ) and HCHO in blue (slant column $2.82 \times 10^{16}$ molec cm $^{-2}$, RMS $1.6 \times 10^{-4}$ ) from 10 October 2009 (03:24 UT, $47.6^{\circ}$ SZA, $2^{\circ}$ viewing angle). The solid line is the scaled cross section (with the scaling factor being the slant column) and the dashed line is the fit (scaled cross section plus fit residual).

ers of $50 \mathrm{~m}$ each (total height $4 \mathrm{~km}$ ). Retrieval studies under different scenarios have shown that this profiling algorithm is capable of reproducing the trace gas column within an error of $20 \%$ and the volume mixing ratio (VMR) in the lowest $500 \mathrm{~m}$ within $25 \%$; for these studies and more information on the principles of MAX-DOAS profile algorithms see Wittrock et al. (2012) and Wittrock (2006).

Similar profiling techniques based on the optimal estimation method have been used recently, e.g. to retrieve $\mathrm{BrO}$ profiles and aerosols in the Arctic (Frieß et al., 2011). HCHO and $\mathrm{NO}_{2}$ vertical distributions have been retrieved in the polluted region of Milan, Italy, using parameterization techniques for block-profiles (Wagner et al., 2011) expecting the trace gases in the boundary layer (or an uplifted layer). In contrast, the troposphere over the remote ocean is considered to be very clean and no sources of $\mathrm{HCHO}$ and $\mathrm{NO}_{2}$ are located at the surface (except for the sparse events of other 
ships passing). The background concentrations are assumed to originate from methane oxidation and lightning events, respectively, and therefore they are not strictly linked to the boundary layer. Thus, no block-profiles but volume mixing ratios decreasing linearly with altitude were used as a priori profiles in the optimal estimation. Retrieved profiles and corresponding a priori profiles are shown exemplarily for $\mathrm{NO}_{2}$ and HCHO in Figs. 10 and 16, respectively.

The sensitivity of a retrieved profile $\mathbf{x}$ to the true profile $\mathbf{x}_{\text {true }}$ is described by the averaging kernel matrix $\mathbf{A}$ :

$$
\mathbf{A}=\frac{\partial \mathbf{x}}{\partial \mathbf{x}_{\text {true }}}
$$

In the absence of a priori constraints, it is $\mathbf{x}=\mathbf{A} \mathbf{x}_{\text {true }}$. Each row of $\mathbf{A}$ is called an averaging kernel and is associated with the retrieved profile point in a certain altitude. The averaging kernel describes then, how this profile point behaves when the true profile in different altitudes changes, i.e. the retrieved profile point is a weighted average of the true profile and the averaging kernel's values represent the weights in different altitudes. Examples of averaging kernels for the $\mathrm{NO}_{2}$ and $\mathrm{HCHO}$ retrieval presented in this work are given in Figs. 10 and 16 in Sects. 4.2 and 4.3. The information content of the profile retrieval depends on the actual viewing conditions and is given by the trace of $\mathbf{A}$. Typical values for the number of degrees of freedom (DOF) range from $\approx 1.5$ to 3 .

For the SCIAMACHY satellite retrieval of $\mathrm{NO}_{2}$, a fitting window from $425-450 \mathrm{~nm}$ was applied. For the stratosphere, only the stratospheric AMF was used and no correction for clouds or the troposphere has been taken into account. For the troposphere, only pixels with $<0.2$ cloud coverage were considered (FRESCO+) (Wang et al., 2008) and a tropospheric AMF based on a MOZART $\mathrm{NO}_{2}$ profile climatology was used. A reference sector (longitude $180-210^{\circ}$ ) was subtracted to correct for the stratospheric $\mathrm{NO}_{2}$ content. The applied DOAS fit settings are explained in detail elsewhere (Richter et al., 2005).

For the GOME-2 retrieval of $\mathrm{NO}_{2}$ similar settings were used, but an extended fitting window from $425-497 \mathrm{~nm}$ was applied (Richter et al., 2011).

For the HCHO retrieval from GOME-2 a fitting window from 337-353 nm was applied (Vrekoussis et al., 2010).

\section{Results}

\subsection{Stratospheric $\mathrm{NO}_{2}$}

In the stratosphere, $\mathrm{NO}_{2}$ undergoes a diurnal cycle due to photolysis of $\mathrm{N}_{2} \mathrm{O}_{5}$, causing $\mathrm{NO}_{2}$ to increase during the course of the day, e.g. a recent study found an increase of

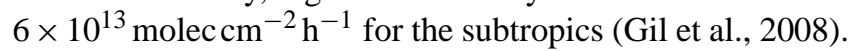
The $\mathrm{N}_{2} \mathrm{O}_{5}$ is built up at night from the reaction of $\mathrm{NO}_{2}$ with $\mathrm{O}_{3}$ and subsequent reactions (Brasseur et al., 1999). As a result of this diurnal cycle, the content of $\mathrm{NO}_{2}$ in the refer-

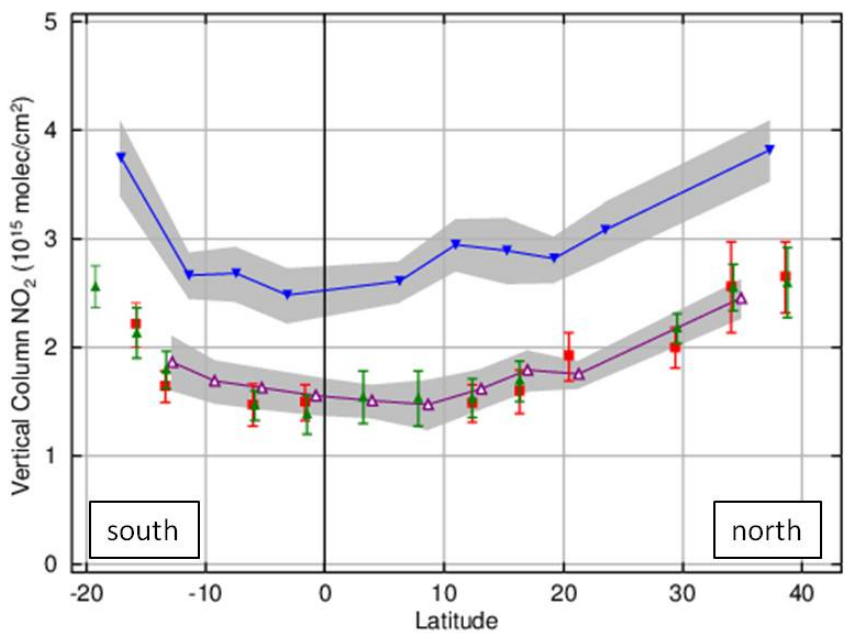

Fig. 4. Stratospheric $\mathrm{NO}_{2}$ vertical columns as a function of latitude, MAX-DOAS morning values in magenta, evening values in blue (grey-shaded area indicates error margin), GOME-2 satellite values are displayed in green, SCIAMACHY satellite values in red (see text).

ence measurement cannot be obtained using a simple Langley plot, as it requires constant conditions during the day. Therefore, a fixed reference measurement was used for the whole campaign taken on 14 October (latitude $20.5^{\circ} \mathrm{N}$ ), as this was the period with best weather and viewing conditions and the region is representative for open ocean conditions with negligible tropospheric $\mathrm{NO}_{2}$ content (see Sect. 4.2 and Fig. 6). The SCIAMACHY and GOME-2 (interpolated) data imply a vertical column of about $1.9 \times 10^{15} \mathrm{molec} \mathrm{cm}^{-2}$ for this day at their overflight times (10:00 LT and 09:30 LT, respectively) when the MAX-DOAS performed measurements at $40^{\circ} \mathrm{SZA}$. Consequently, the slant column of this reference measurement was estimated to be

$\mathrm{SC}_{\mathrm{ref}}=\mathrm{AMF} \cdot \mathrm{VC}_{\mathrm{ref}} \approx \frac{1.9 \times 10^{15}}{\cos (40)} \approx 2.5 \times 10^{15} \frac{\mathrm{molec}}{\mathrm{cm}^{2}}$.

This reference SC was added to daily twilight measurements taken between $88^{\circ}$ and $92^{\circ}$ SZA and calculated air mass factors (Sect. 3.5) were used to obtain vertical columns that were averaged for a.m. and p.m., and plotted in Fig. 4. An uncertainty of $30 \%$ of the reference vertical column would correspond to $\approx 0.7 \times 10^{15}$ molec $\mathrm{cm}^{-2}$ in the reference slant column, which is added to the twilight measurements. With an air mass factor of $\approx 18$ for measurements taken at $90^{\circ} \mathrm{SZA}$, this would lead to an uncertainty of $0.04 \times 10^{15} \mathrm{molec} \mathrm{cm}^{-2}$, which is negligible (compared to values in Fig. 4). The tropospheric $\mathrm{NO}_{2}$ column across the ocean is even lower than $0.7 \times 10^{15} \mathrm{molec} \mathrm{cm}^{-2}$ (see Sect. 4.2) and has therefore been neglected.

As described in Sect. 3.5, for practical reasons the US standard atmosphere was used to calculate air mass factors. This is an approximation, because the true stratospheric $\mathrm{NO}_{2}$ 


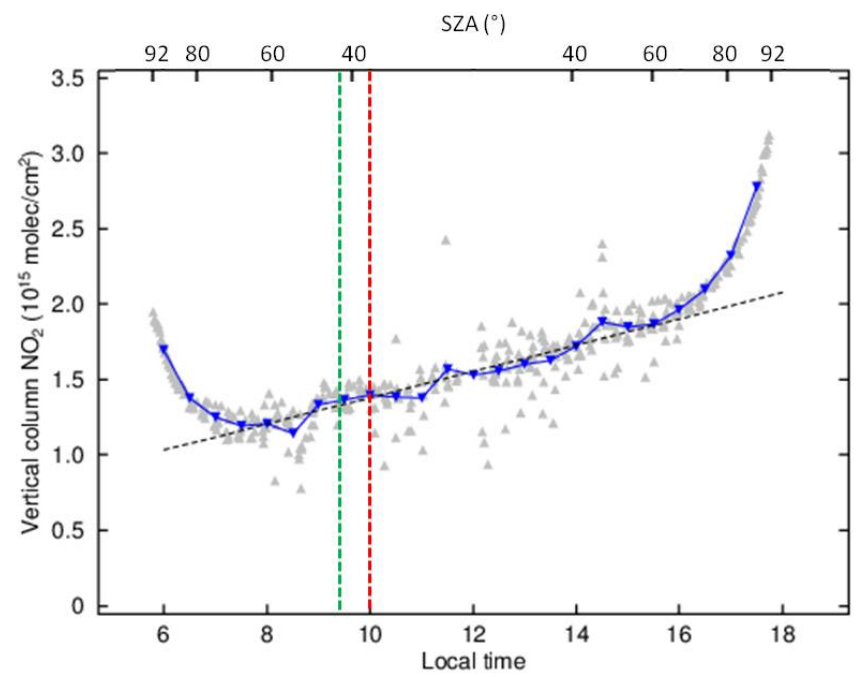

Fig. 5. Diurnal cycle of stratospheric $\mathrm{NO}_{2}$ vertical columns on 15 October 2009 (grey: single measurements, blue: data binned to $0.5 \mathrm{~h}$ resolution). The black dashed line is the derived daytime linear increase, the green dashed line gives the approximate GOME-2 overpass time and the red line the SCIAMACHY overpass.

profile is unknown. Furthermore, the $\mathrm{NO}_{2}$ changes rapidly during twilight due to photochemistry, i.e. its profile is a function of SZA. As a consequence of the curvature of the Earth and the drastically extended light path during twilight, the photons experience different $\mathrm{NO}_{2}$ profiles coupled to the local SZA on their way through the stratosphere. This can be considered by applying the actual $\mathrm{NO}_{2}$ concentrations for each point of the light path, which are derived from a photochemical model (e.g., Hendrick et al., 2006, and references therein). Nevertheless, for a tropical scenario and SZAs between $89^{\circ}$ and $91^{\circ}$, Gil et al. (2008) showed that the difference between air mass factors calculated with the standard atmosphere and more accurate air mass factors using profiles from a climatology is in the order of $5 \%$. This is in the range of errors in Fig. 4. To account for the effect of unknown $\mathrm{NO}_{2}$ profiles and other potential error sources related to the radiative transfer modeling, the air mass factors used for converting slant columns into vertical columns as described above were changed (arbitrarily) by 1 . Then, vertical columns were calculated again and the differences to the original results are used as error margin.

In Fig. 4 the stratospheric $\mathrm{NO}_{2}$ vertical columns (a.m. and p.m. values) from MAX-DOAS are displayed as a function of latitude (see also Fig. 1 for the cruise track) in comparison to GOME-2 and SCIAMACHY satellite values. GOME-2 satellite pixels were averaged within a $200 \mathrm{~km}$ radius around the ship's position at the overflight time (for the location of GOME-2 satellite pixels being averaged, see Fig. 1b). For the SCIAMACHY instrument, averages within a $400 \mathrm{~km}$ radius were calculated to account for its sparser spatial coverage. All vertical columns shown in Fig. 4 are summarized in Table 2 .
Both the MAX-DOAS a.m. and p.m. values as well as the satellite values show a characteristic U-shape with latitude. MAX-DOAS a.m. values range from $2.3 \times 10^{15} \mathrm{molec}^{-2}$ at $35^{\circ} \mathrm{N}$ to $1.3 \times 10^{15} \mathrm{molec} \mathrm{cm}^{-2}$ across the Equator and increase to $1.8 \times 10^{15} \mathrm{molec}^{-2}$ at $13^{\circ} \mathrm{S}$ (note that especially at the beginning of the cruise values are missing due to instrumental problems and data with bad wind directions that were removed). MAX-DOAS p.m. values slowly decrease from $3.8 \times 10^{15} \mathrm{molec} \mathrm{cm}^{-2}$ at $38^{\circ} \mathrm{N}$ to $2.5 \times 10^{15} \mathrm{molec} \mathrm{cm}^{-2}$ at the Equator and increase again to $3.8 \times 10^{15}$ molec $^{-2}$ at $19^{\circ} \mathrm{S}$. This general shape is in good agreement with results from a previous campaign performed in the Atlantic ocean (Kreher et al., 1995) while absolute values seem to be slightly smaller.

Figure 5 shows exemplarily the diurnal cycle derived from MAX-DOAS measurements on 15 October 2009 (latitude $16.4^{\circ} \mathrm{N}$ ). For this figure, AMFs have been calculated not only for measurements between $88^{\circ}$ and $92^{\circ}$ SZA, being most sensitive to stratospheric absorbers due to the long light path in the stratosphere, but for all measurements. The sensitivity decreases rapidly for small SZAs since the light path through the stratosphere diminishes. Consequently, the variance in retrieved $\mathrm{NO}_{2}$ columns (grey data points in Fig. 5) increases. In order to increase the number of measurements yielding better statistics, all viewing directions $>5^{\circ}$ elevation angle were considered to contain only stratospheric $\mathrm{NO}_{2}$ signals. This is a reasonable assumption as 15 October 2009 had open ocean conditions with negligible tropospheric $\mathrm{NO}_{2}$ content (see Sect. 4.2 and Fig. 6). The resulting vertical columns (grey data points in Fig. 5) have been binned to $0.5 \mathrm{~h}$ steps (blue data points). After the a.m. value (88-92 ${ }^{\circ} \mathrm{SZA}$ average), the stratospheric $\mathrm{NO}_{2}$ columns decrease towards a minimum and increase afterwards, reproducing the a.m. value around noon. A linear regression between 07:00 LT and 16:00 LT yields a slope of about $(8.7 \pm 0.5) \times 10^{13} \mathrm{molec} \mathrm{cm}^{-2} \mathrm{~h}^{-1}$ (indicated by the black dashed line). Consequently, the satellite values in Fig. 4 should be $\approx 1.7 \times 10^{14}$ molec $^{-2}$ lower than MAX-DOAS a.m. values due to their overflight time, which is slightly more than observed but in agreement with most of the observations considering the error bars (see Fig. 4). At the beginning of the campaign, on 10 and 11 October 2009 (latitudes $38.7^{\circ}$ and $34.1^{\circ} \mathrm{N}$ ), the satellite pixels considered for the comparison include areas over or close to Japan (Fig. 1b), a region of high anthropogenic pollution, meaning that polluted pixels may affect the satellite averages.

For the whole dataset shown in Fig. 4 (see values in Table 2), SCIAMACHY and GOME-2 agree with each other within their standard deviations resulting from spatial averaging (error bars of satellite data). The mean difference between the satellite instruments for this analysis is $(0.26 \pm$ 1.02 ) $\times 10^{14}$ molec cm$^{-2}$ (corresponding to $\approx 1-1.7 \%$ of the vertical column). While reproducing the same latitudinal shape as the MAX-DOAS data, SCIAMACHY is on average $(0.68 \pm 1.52) \times 10^{14} \mathrm{molec}^{-2}$ and GOME-2 $(0.45 \pm$ 1.02) $\times 10^{14}$ molec $\mathrm{cm}^{-2}$ lower than the MAX-DOAS a.m. 
Table 2. Stratospheric $\mathrm{NO}_{2}$ vertical columns as observed from MAX-DOAS, SCIAMACHY and GOME-2 (see also Fig. 4). All values are given in $10^{15}$ molec $\mathrm{cm}^{-2} . \Delta_{\text {MD-SCIA }}$ is the difference between the MAX-DOAS a.m. value and the SCIAMACHY value of the corresponding day ( $\Delta_{\text {MD-GOME-2 }}$ accordingly) and $\Delta_{\text {SCIA-GOME-2 }}$ is the difference between the satellite instruments. The last two rows give the mean and the standard deviation of the differences. As all observations differ in time and location from each other, the latitude (2nd column) is only an approximate value corresponding to the ship's location at noon (12 h) local time.

\begin{tabular}{crcccrrrr}
\hline Day & Latitude & MAX-DOAS a.m. & MAX-DOAS p.m. & SCIA & GOME-2 & $\Delta_{\text {MD-SCIA }}$ & $\Delta_{\text {MD-GOME-2 }}$ & $\Delta_{\text {SCIA-GOME-2 }}$ \\
\hline 10 Oct & 38.29 & - & 3.82 & 2.65 & 2.60 & - & - & 0.05 \\
11 Oct & 33.70 & 2.45 & - & 2.56 & 2.55 & -0.11 & -0.1 & 0.01 \\
12 Oct & 28.98 & - & - & 2.00 & 2.18 & - & - & -0.18 \\
13 Oct & 24.47 & - & 3.08 & - & - & - & - & - \\
14 Oct & 20.26 & 1.75 & 2.81 & 1.92 & - & -0.17 & - & - \\
15 Oct & 16.05 & 1.79 & 2.89 & 1.59 & 1.69 & 0.2 & 0.1 & -0.1 \\
16 Oct & 12.01 & 1.62 & 2.94 & 1.49 & 1.54 & 0.13 & 0.08 & -0.05 \\
17 Oct & 7.41 & 1.47 & 2.61 & - & 1.54 & - & -0.07 & - \\
18 Oct & 2.73 & 1.50 & - & - & 1.54 & - & -0.04 & - \\
19 Oct & -1.98 & 1.55 & 2.48 & 1.49 & 1.38 & 0.06 & 0.17 & 0.11 \\
20 Oct & -6.46 & 1.62 & 2.68 & 1.47 & 1.47 & 0.15 & 0.15 & - \\
21 Oct & -10.34 & 1.68 & 2.66 & - & - & - & - & - \\
22 Oct & -13.53 & 1.86 & - & 1.64 & 1.79 & 0.22 & 0.07 & -0.15 \\
23 Oct & -16.06 & - & 3.75 & 2.21 & 2.13 & - & - & 0.08 \\
24 Oct & -19.25 & - & - & - & 2.56 & - & - & - \\
\hline mean all & & & & & & 0.068 & 0.045 & -0.026 \\
stdv & & & & & & \pm 0.152 & \pm 0.102 & \pm 0.102 \\
\hline
\end{tabular}

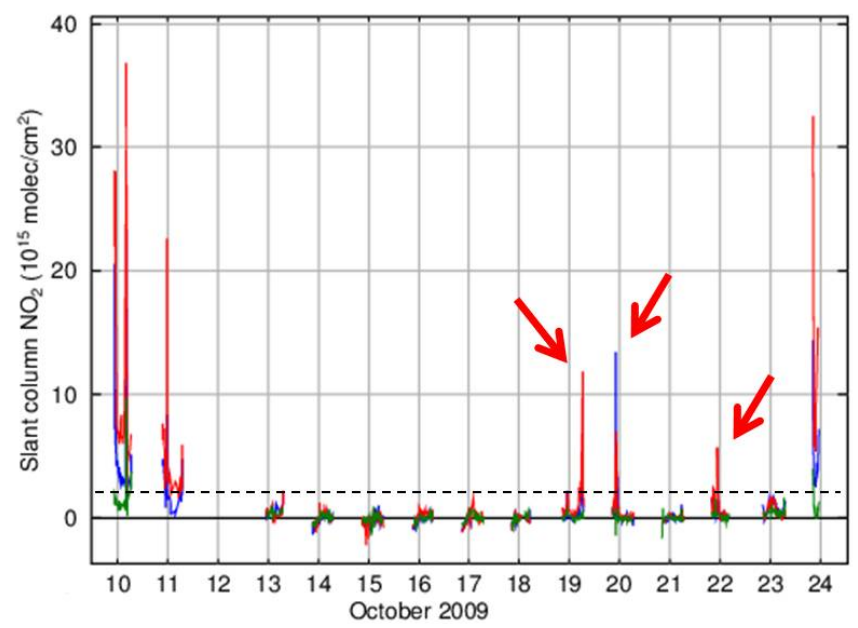

Fig. 6. Color-coded tropospheric $\mathrm{NO}_{2}$ slant columns (red $=2^{\circ}$, blue $=8^{\circ}$, green $=30^{\circ}$ viewing direction). The dashed line indicates the estimated detection limit. The red arrows marking three $\mathrm{NO}_{2}$ events over the remote ocean correspond to the red arrows in Fig. 1c indicating the ship's position during these events.

values, as a consequence of the stratospheric $\mathrm{NO}_{2}$ diurnal cycle as discussed above.

\subsection{Tropospheric $\mathrm{NO}_{2}$}

At low latitudes, the large concentration of water vapor in the humid air above the warm ocean's surface potentially lim- its the accuracy of the MAX-DOAS measurements as small misfits of $\mathrm{H}_{2} \mathrm{O}$ would dominate the DOAS fit residual. This has been seen under similar conditions by Takashima et al. (2011) where it is discussed in detail. Here we could avoid this problem by using the Hitran 2009 update for the water vapor cross section (HITRAN database, http://www.cfa. harvard.edu/hitran/) and the fitting window between 450 and $497 \mathrm{~nm}$.

Figure 6 shows all retrieved $\mathrm{NO}_{2}$ slant columns throughout the whole cruise that were taken under wind directions preventing the ship's exhaust plume to contaminate the measurements (see Sect. 3.4). As a result, no data is displayed for 12 October 2009. In addition, suspicious high and sharp (shorttime) peaks, especially when showing larger slant columns in high elevation angles, were removed as being most probably due to wind gusts blowing the plume into the instrument's line of sight (the distance between the instrument and the exhaust plume was only a few meters). As the MAX-DOAS measurements from the southward moving ship will contain a contribution from stratospheric $\mathrm{NO}_{2}$, which shows a latitudinal variation (see Sect. 4.1) for each measurement, the closest zenith ${ }^{2}$ measurement was chosen as reference to minimize the stratospheric $\mathrm{NO}_{2}$ signal. For comparison, Fig. 7

\footnotetext{
${ }^{2}$ Note that for 11 October almost no zenith measurements exist due to instrumental problems and the $30^{\circ}$ elevation was chosen as reference, which will strongly reduce the sensitivity towards $\mathrm{NO}_{2}$ in the free troposphere; nevertheless, it turned out that the $\mathrm{NO}_{2}$ is close to the surface (Fig. 9) providing a possibility to achieve reasonable results even using the $30^{\circ}$ reference for $\mathrm{NO}_{2}$ measurements.
} 


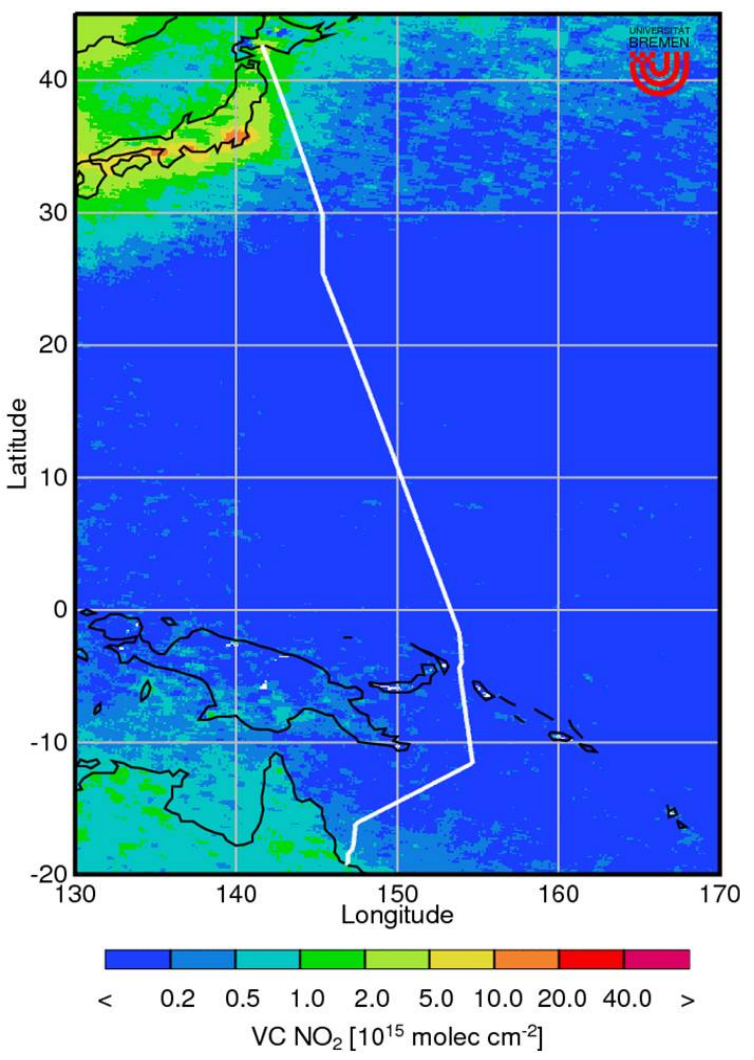

Fig. 7. October 2009 monthly average of tropospheric $\mathrm{NO}_{2}$ from GOME-2 (scientific product from Institute of Environmental Physics, University of Bremen). The Cruise Track is indicated by the white line. After the first days, having influences from Japan, a region of pure $\mathrm{NO}_{2}$ background concentration is encountered.

shows the monthly mean tropospheric $\mathrm{NO}_{2}$ vertical columns as observed from the spaceborne GOME-2 instrument.

The elevation angle in Fig. 6 is color-coded. At the beginning and at the end of the cruise, smaller elevations yield higher slant columns, as the light path through the trace gas layer is longer (this information is used for the profiling retrieval). After the first days of the cruise, having influences from Japan (Figs. 1 and 7), no split-up of different viewing directions is observed and $\mathrm{NO}_{2}$ values decrease towards an estimated detection limit (the estimation is performed below). Elevated tropospheric $\mathrm{NO}_{2}$ columns in the clean air over the open ocean were detected only for three events (arrows in Fig. 6) corresponding to the position of the ship indicated by red arrows in Fig. 1c. Also on 10 and 11 October, being in the polluted marine environment close to Japan, peaks were found in the dataset. For all events, lower elevation angles show enhanced $\mathrm{NO}_{2}$ slant columns while the $\mathrm{NO}_{2}$ at $30^{\circ}$ elevation angle is not affected. This behavior indicates that the observed $\mathrm{NO}_{2}$ is close to the ground and not originating from our ship's plume, as this would increase the $30^{\circ}$ elevation angle more than elevation angles close to the horizon. The spikes on 11 and 20 October are short-in-time and

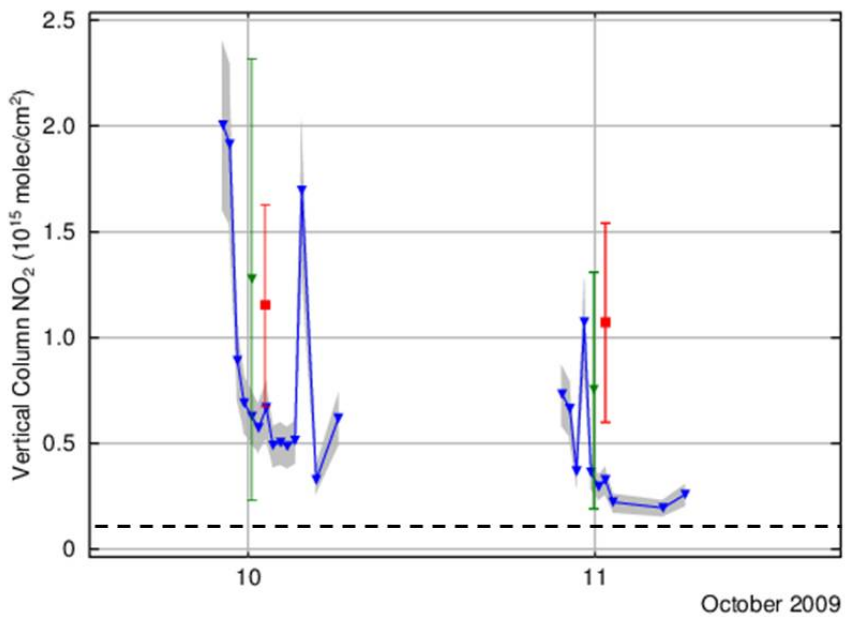

Fig. 8. Retrieved vertical $\mathrm{NO}_{2}$ columns from MAX-DOAS measurements for 10 and 11 October 2009 in blue (error margin plotted as grey-shaded area), GOME-2 values in green (satellite pixels averaged within $150 \mathrm{~km}$ around ship's position at time of overflight) and SCIAMACHY values in red $(200 \mathrm{~km}$ radius $)$. The dashed line indicates the MAX-DOAS detection limit.

affect only measurements within single scans. These events could be assigned to other ship plumes as the video camera in our telescope housing detected other ships passing exactly at the time of these peaks. In comparison to these high and short-term events, elevated levels of $\mathrm{NO}_{2}$ on 22 October are lower but persist for a time span of $\approx 3 \mathrm{~h}$. The video camera did not detect any other vessels for this event, but Fig. 1c indicates the crossing of a clearly preferred shipping route. Higher concentrations of $\mathrm{NO}_{2}$ along frequently used shipping routes is a known issue having been observed from spaceborne platforms (e.g. Beirle et al., 2004; Richter et al., 2004). The origin of the events on 10 October remaining for $\approx 1 \mathrm{~h}$ is unclear. Backward trajectories calculated with the online tool HYSPLIT reach back to the Japanese mainland on 10 October, so that influences from the close Japanese coast (i.e. passing of towns, industrial regions) can be an explanation. The event in the evening of 19 October consists of multiple scans with increasing $\mathrm{NO}_{2}$ slant columns, a clear maximum of $12 \times 10^{15}$ molec $^{-2}$ and a rapid decrease afterwards. Emissions from other vessels missed by our telescope camera are a possible explanation. In addition, this event coincides with elevated levels of formaldehyde in the evening of 19 October when the research vessel approaches a minimal distance $(150 \mathrm{~km})$ to the island of New Ireland (see cruise track in Fig. 1 and also Fig. 13 in Sect. 4.3). At the same time, calculated backward trajectories reach back to New Ireland as well. Consequently, also transport events are a possible explanation for the observed elevated levels (see discussion in Sect. 4.3).

For the first days of the cruise (10-11 October 2009) the profiling software BREAM (see Sect. 3.5) was used to calculate tropospheric $\mathrm{NO}_{2}$ vertical columns (Fig. 8) and profiles 

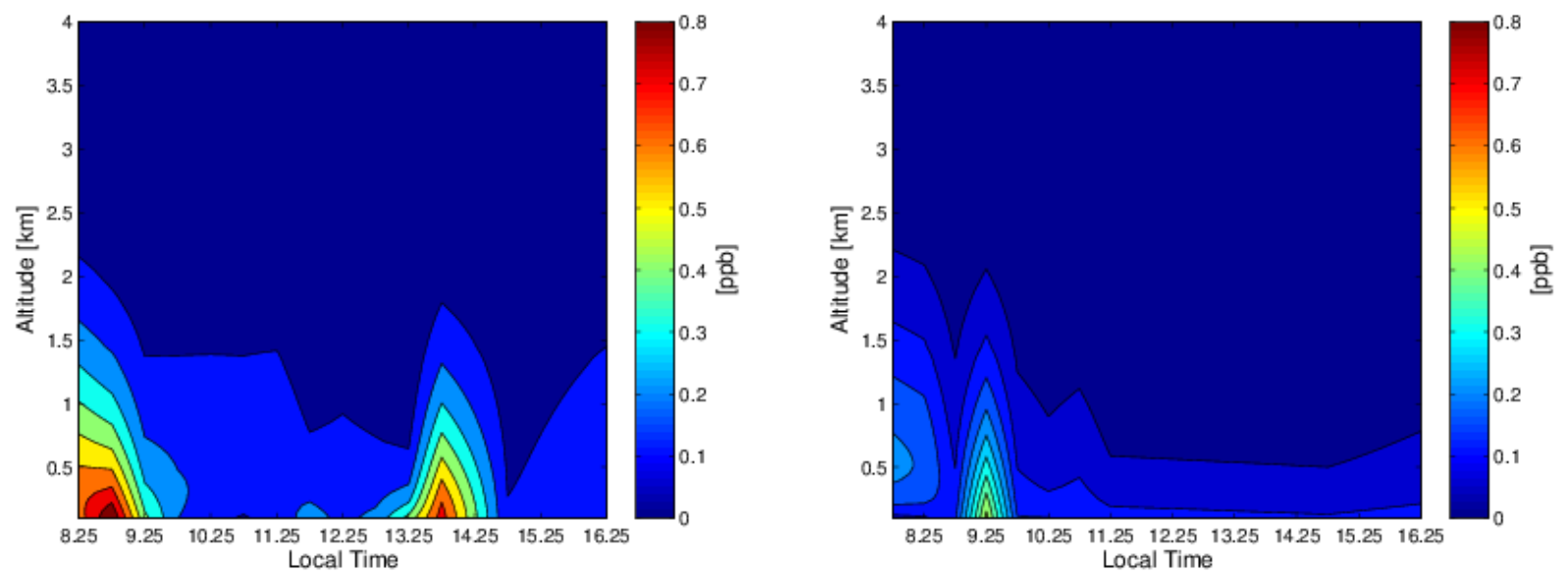

Fig. 9. Retrieved tropospheric $\mathrm{NO}_{2}$ profiles for 10 October (left) and 11 October (right). Highest $\mathrm{NO}_{2}$ concentrations are found close to the ground.
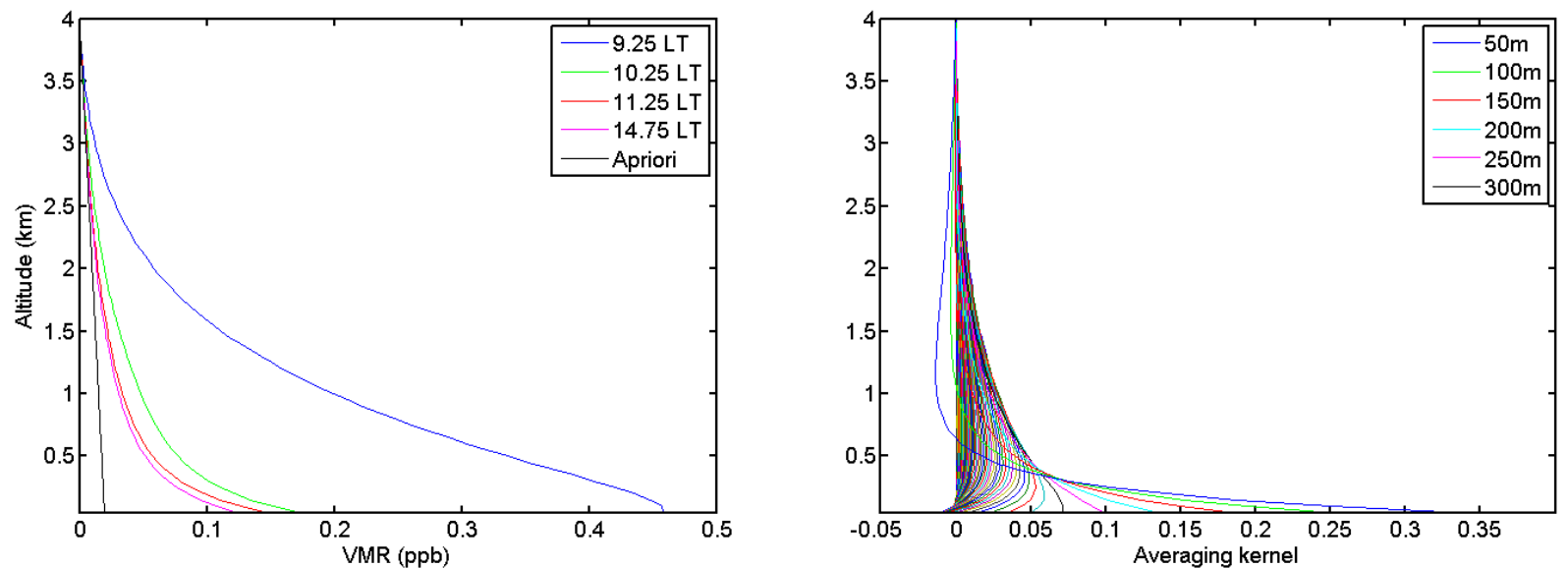

Fig. 10. Left: example profiles of $\mathrm{NO}_{2}$ from 11 October 2009 (corresponding to Fig. 9, right). The 09:25 LT profile is the distinct peak that was verified as another ship's plume. Right: exemplarily averaging kernels of the retrieved profile on 11 October 2009, 10:25 LT (green profile on the left).

(Fig. 9). As Fig. 9 shows, maximum $\mathrm{NO}_{2}$ concentrations are observed close to the ground. Apart from the peaks as discussed above (yielding up to $0.8 \mathrm{ppbv}$ peak concentrations), the background concentrations do not exceed $0.2 \mathrm{ppbv}$, even in the polluted marine environment close to Japan. Figure 10 (left picture) shows exemplarily some retrieved profiles from 11 October 2009 together with the a priori profile used in the retrieval. In Fig. 10 (right picture), typical averaging kernels are shown (from 11 October 2009, 10:25 LT; for this day, the $30^{\circ}$ measurements were used as reference). The averaging kernels associated with different points of the retrieved profile are color-coded. Especially the lowest points of the retrieved profile exhibit an increasing sensitivity to the true profile close to the ground. For this example, the degrees of freedom are $\approx 1.6$.

For the tropospheric $\mathrm{NO}_{2}$ column and concentration above the open ocean, where $\mathrm{NO}_{2}$ slant columns were close to the detection limit (Fig. 6), an upper limit has been estimated. Best RMS of the tropospheric $\mathrm{NO}_{2}$-Fits are $\approx 1 \times 10^{-4}$ and the differential $\mathrm{NO}_{2}$ absorption cross section is in the order of $1 \times 10^{-19} \mathrm{~cm}^{2} \mathrm{molec}^{-1}$. Assuming intuitively that an optical density of twice the RMS can be detected, a detection limit (DL) of $2 \times 10^{15} \mathrm{molec} \mathrm{cm}^{-2}$ for the slant column can be estimated. (Note that an even smaller DL of $\approx 3 \times 10^{-14}$ molec $\mathrm{cm}^{-2}$ is obtained from the formula given by Platt and Stutz (2008), i.e. the DL following the intuitive approach can be regarded as an upper estimate.) This corresponds to a vertical column of $\approx 1.3 \times 10^{14} \mathrm{molec} \mathrm{cm}^{-2}$ with a typical air mass factor of 15 for low elevation angles. Under the assumption of a block-profile of $1 \mathrm{~km}$ mixing layer height (MLH), this vertical column (VC) yields a volume mixing ratio (VMR) of

$\mathrm{VMR}=\frac{\mathrm{VC}}{\mathrm{MLH}} \cdot \frac{k_{\mathrm{B}} \cdot T}{p} \approx 50 \mathrm{pptv}$, 


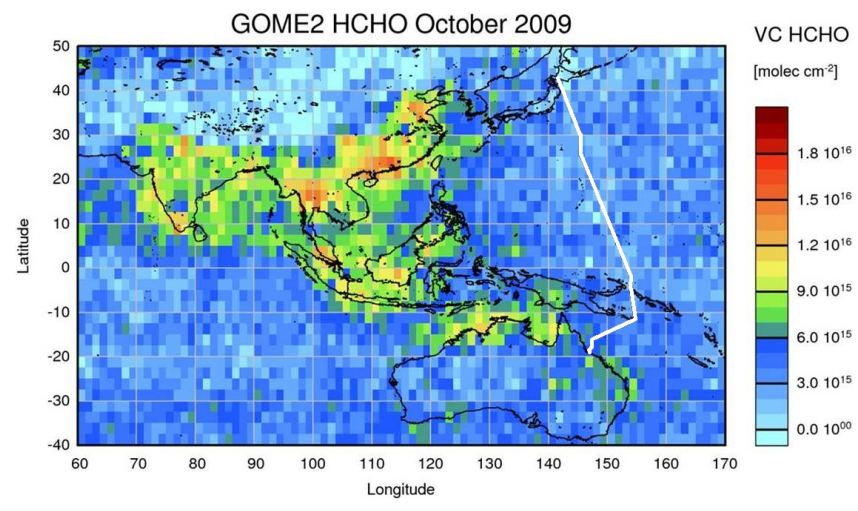

Fig. 11. October 2009 monthly average of tropospheric formaldehyde from the GOME-2 instrument (scientific product from Institute of Environmental Physics, University of Bremen). Measured HCHO columns during TransBrom (the cruise track is indicated) are background concentrations from methane oxidation (possible anthropogenic contributions at the beginning and end of the cruise).

with the Boltzmann constant $k_{\mathrm{B}}, T=300 \mathrm{~K}$ and $p=1 \times$ $10^{5} \mathrm{~Pa}$. This detection limit can be regarded as an upper limit for the tropospheric $\mathrm{NO}_{2}$ column under clean open ocean conditions, which is less than reported by Takashima et al. (2011) who found $0.2 \mathrm{ppbv}$ as an upper limit for the marine background concentration of $\mathrm{NO}_{2}$ in the lowest $1000 \mathrm{~m}$.

Tropospheric vertical columns derived from GOME-2 and SCIAMACHY satellite measurements are shown in Fig. 8 as color-coded data points in comparison to the MAX-DOAS values (blue points). The MAX-DOAS error margin (greyshaded area) corresponds to a worst case error of $20 \%$ of the vertical columns resulting from sensitivity tests (Wittrock et al., 2012). For the comparison presented here, all satellite pixels within a $150 \mathrm{~km}$ radius around the ship's position at the time of the overflight were averaged for GOME-2 (for SCIAMACHY, $200 \mathrm{~km}$ averages have been calculated to account for the poorer spatial coverage). As a consequence of the spatial averaging, pixels over or close to Japan may increase the satellite averages, as there is a strong gradient in $\mathrm{NO}_{2}$ pollution from land to ocean (see Fig. 7). This also results in the large standard deviations displayed as satellite error bars in Fig. 8. As a result, the satellite averages are 2-3 times higher than corresponding MAX-DOAS measurements, but agree within their standard deviations.

For the open ocean, satellite vertical columns from GOME-2 monthly average are $<2 \times 10^{14}$ molec cm $^{-2}$ (Fig. 7), which is below the estimated uncertainty of the satellite (Boersma et al., 2004), but in good agreement with the background vertical column of $1.3 \times 10^{14}$ molec cm $^{-2}$ derived from MAX-DOAS data.

\subsection{Tropospheric $\mathrm{HCHO}$}

Source regions of formaldehyde (e.g., rain forests emitting precursors and direct anthropogenic emissions from indus-

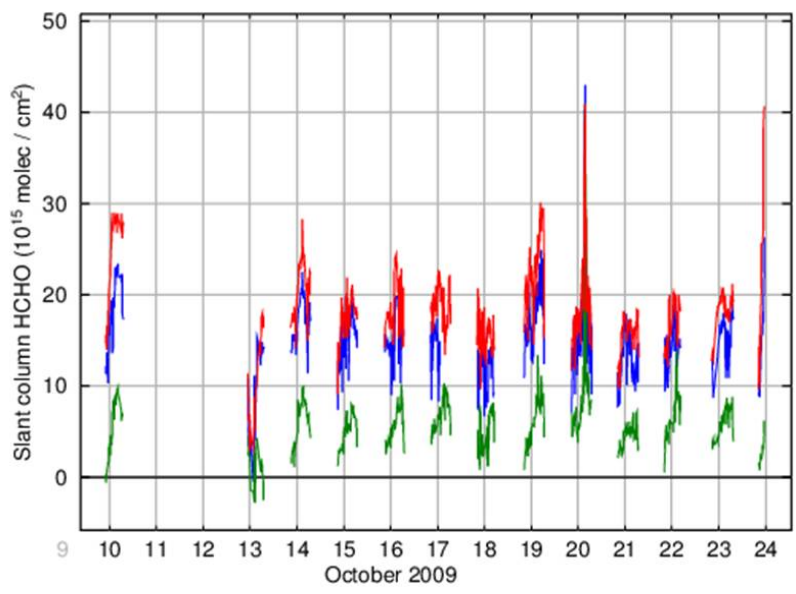

Fig. 12. Color-coded formaldehyde slant columns $\left(\right.$ red $=2^{\circ}$, blue $=$ $8^{\circ}$, green $=30^{\circ}$ elevation angle). Different viewing directions clearly split up for the whole campaign, indicating a background level of HCHO in the marine boundary layer. No data is shown for 11 and 12 October due to a lack of zenith measurements (used as reference, see text) on 11 October and bad wind directions on 12 October.

try) can be identified from space, as Fig. 11 illustrates. The cruise track indicated in Fig. 11 implies that the MAX-DOAS formaldehyde measurements performed during TransBrom are far away from these source regions providing therefore the opportunity to investigate the formaldehyde background concentration and evaluating the accuracy of satellite measurements of small formaldehyde columns over the ocean.

In contrast to $\mathrm{NO}_{2}$, no formaldehyde is expected to be in the stratosphere and therefore no stratospheric contribution has to be accounted for (i.e. by using the closest zenith spectrum as a reference). For the formaldehyde DOAS-fit, a daily reference spectrum at $45^{\circ} \mathrm{SZA}$ was used, as the fit quality turned out to decrease using zenith measurements at small SZAs especially in the tropics.

In Fig. 12, the formaldehyde slant columns for the whole cruise are shown. Different viewing angles (color-coded) are separated clearly from each other, except for periods with bad weather. For example, the low HCHO slant columns on 13 October are a consequence of heavy rain (wash out) in the morning (the formaldehyde slant columns recover after the strong rain but do not reach the level of other days' slant columns). The dominant peak on 20 October is the consequence of a light path extension in sea fog (the oxygen dimer $\mathrm{O}_{4}$ shows a peak at the same time and the camera in our telescope housing shows a nebulous scene).

Apart from this event, the highest formaldehyde columns were obtained on 10 October (being in the polluted marine environment near Japan, compare Fig. 1c) and 24 October (approaching Australia's coast). Although the measurements were already stopped in the morning hours of 24 October when arriving in Townsville, Australia, a remarkable 
increase of formaldehyde slant columns was observed during the few hours of operation when approaching the coast, most likely connected to bush fires, as it was dry season and a lot of fires were observed in the next vicinity even by eye.

14 October (being on the open ocean, see Fig. 1) was the sunniest day of the cruise with best viewing conditions and lowest cloud coverage (the only completely cloud-free period throughout the cruise was around noon) going along with a local maximum in the $\mathrm{HCHO}$ time series. Thus, this maximum indicates that the observed formaldehyde results in large part from methane oxidation and subsequent $\mathrm{HCHO}$ production, which depends on sunlight. However, elevated levels of dimethyl sulfide (DMS) were measured when air masses were reaching the ship from the open ocean (see Fig. 1a for backward trajectories) in the afternoon of 14 October (B. Quack, personal communication, 2012). It can be speculated that other compounds having oceanic sources and being precursors for $\mathrm{HCHO}$ (e.g., aldehydes, methanol) are increased in these air masses as well. Former studies showed that methane is the major source for formaldehyde in very remote regions, but chemical models including only methane tend to underestimate observed formaldehyde concentrations (e.g., Still et al., 2006, and references therein). Thus, the observed formaldehyde during TransBrom is considered to originate mostly (but not entirely) from methane oxidation. In addition, other precursor species (from oceanic sources) give possibly rise to the observed $\mathrm{HCHO}$ level, especially to the peak on 14 October (coinciding with DMS).

A second local maximum in the formaldehyde time series was found in the evening of 19 October, dominated by almost complete cloud coverage making enhanced methane oxidation (depending on sunlight) an implausible source. However, these measurements of enhanced formaldehyde were not performed on the open ocean, but close $(\approx 150 \mathrm{~km})$ to New Ireland ${ }^{3}$ as shown in Fig. 13 (being a zoom-in of Fig. 1). In addition, $24 \mathrm{~h}$ backward trajectories (displayed in green) were calculated with the NOAA HYSPLIT model using the same settings as in Fig. 1a (starting point in a distance of $10 \mathrm{~km}$ off the ship in the viewing direction of our instrument and in an altitude of $350 \mathrm{~m}$ a.s.1.). The trajectories starting in the afternoon of 19 October reach back to the island groups of Tabar and Lihir after $12 \mathrm{~h}$ and to the island of New Ireland after less than $18 \mathrm{~h}$. Backward trajectories starting in the evening of 19 October reach back to the island of New Ireland after $\approx 12 \mathrm{~h}$ (closest distance to the island $\approx 150 \mathrm{~km}$ in the evening of 19 October, which coincides with this day's

\footnotetext{
${ }^{3}$ New Ireland Province is part of the Bismarck Archipelago and the most northeastern province of Papua New Guinea encompassing the largest island of the province called New Ireland and numerous smaller islands including the Tabar and Lihir group at the Pacific side (the latter is famous for housing a gold mine holding one of the world's largest gold resources). The island of New Ireland has a length of $\approx 400 \mathrm{~km}$ but a width of mostly less than $10 \mathrm{~km}$. The terrain is dominated by a central mountainous spine, the vegetation is tropical rainforest.
}

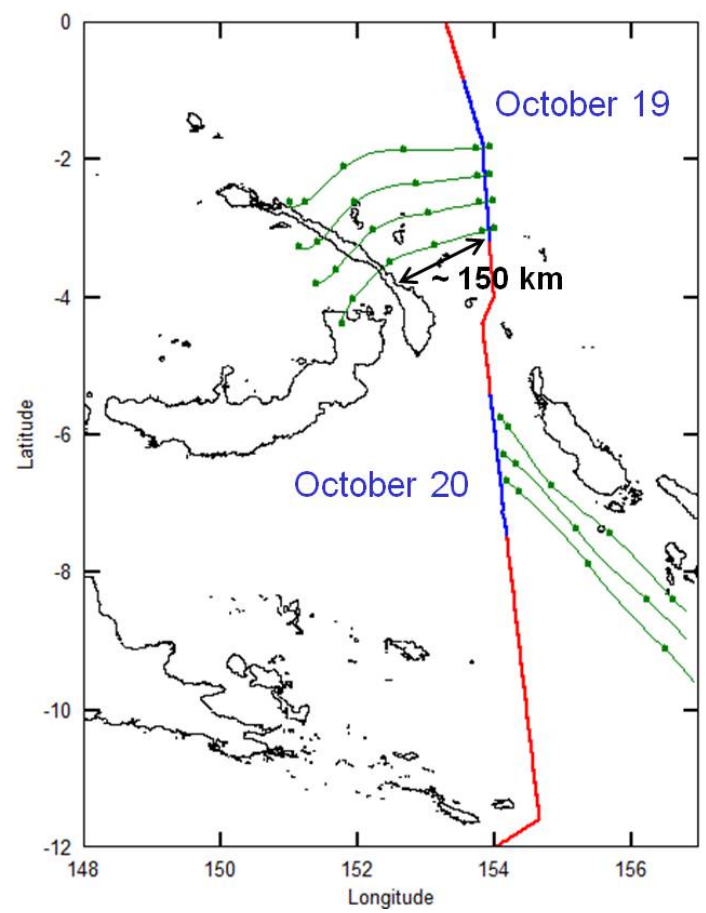

Fig. 13. Detail map of the TransBrom cruise. Blue parts indicate 19 and 20 October daytime, when MAX-DOAS measurements were performed. Backward trajectories are displayed in green, marks meaning: starting point, $-1,-6,-12,-18$ and $-24 \mathrm{~h}$, respectively.

HCHO maximum). Thus, the enhanced formaldehyde on 19 October, especially in the evening, is most probably a result of formaldehyde precursor transport from rainforest. On the next day, 20 October, Fig. 13 shows that the wind direction changed transporting clean air masses from the open sea to our position, resulting in lower formaldehyde slant columns.

Profiles and vertical columns of formaldehyde have been calculated using the profiling software BREAM (Sect. 3.5) consistent to the retrieval of tropospheric $\mathrm{NO}_{2}$ (Sect. 4.2). Tropospheric HCHO columns were retrieved successfully during the whole cruise above an estimated detection limit of $0.5 \times 10^{15} \mathrm{molec} \mathrm{cm}^{-2}$ (Fig. 14). The detection limit has been estimated using the same method applied for tropospheric $\mathrm{NO}_{2}$. Again, this can be regarded as upper limit as the detection limit according to Platt and Stutz (2008) yields a value of $\approx 0.1 \times 10^{15} \mathrm{molec} \mathrm{cm}^{-2}$ for the vertical column. The time series shown in Fig. 14 reproduce the local maxima as discussed above, plotted error bars correspond again to a worst case error of $20 \%$. In addition, the vertical columns exhibit a diurnal cycle with low values in the morning and evening and maxima around noon, most clearly on days with good weather and viewing conditions, especially on 14 October.

As an example, Fig. 15 shows all retrieved profiles for 14 and 15 October, both having reasonable viewing conditions, although not being completely cloud-free. Exemplarily, profiles together with the a priori profile used for the retrieval 


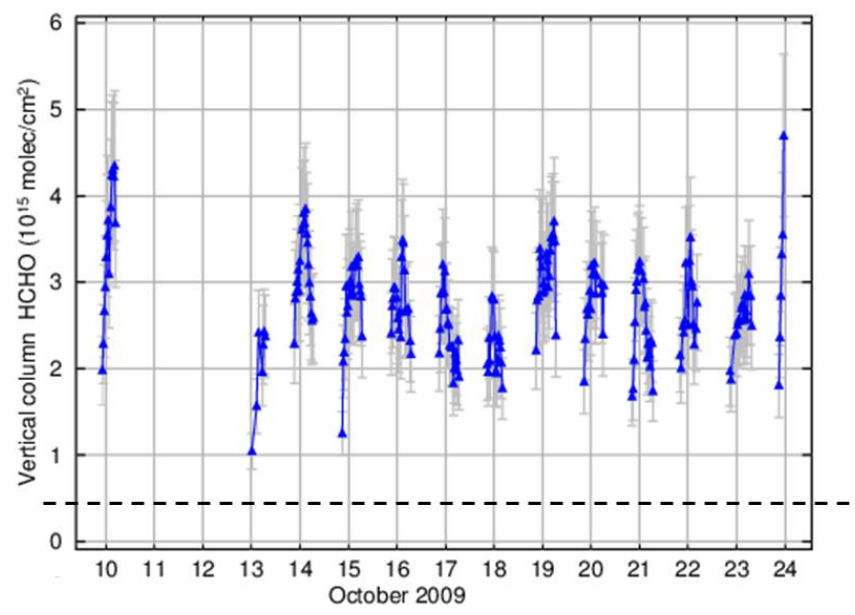

Fig. 14. Time series of the retrieved tropospheric HCHO vertical columns. The dashed line indicates the MAX-DOAS detection limit.

can be found also in Fig. 16 (left picture). Figure 16 (right picture) shows averaging kernels for the retrieval on 14 October 2009, 09:25 LT (DOF $\approx 1.8$, the corresponding profile is displayed in the left picture). As already seen for tropospheric $\mathrm{NO}_{2}$, the retrieved $\mathrm{HCHO}$ profile is most sensitive in low altitudes to the true profile close to the ground.

14 October (Fig. 15, left picture) had the lowest cloud coverage throughout the whole cruise with a completely cloud-free period around noon when highest concentrations of $1.1 \mathrm{ppbv}$ occurred. In contrast, 15 October (Fig. 15, right picture) had its best viewing conditions (rarely cloudy) in the afternoon to evening, partial to full cloud coverage in the morning and a short rain event at noon, most likely suppressing a midday's maximum as seen on 14 October. The better viewing conditions on 14 October also result in a smoother shape of concentration isolines compared to 15 October. Both days show a diurnal cycle with enhanced levels of formaldehyde during noon/afternoon when the sunlight intensity driving the formaldehyde production is highest. Corresponding peak concentrations of $1.1 \mathrm{ppbv}$ were found on 14 October at noon-time. In comparison to $\mathrm{NO}_{2}$, showing highest concentrations close to the ground (see Fig. 9), formaldehyde's highest concentrations occur in elevated altitudes (in the $400 \mathrm{~m}$ regime) during the day. Apart from the midday's maximum, $\mathrm{HCHO}$ levels in the afternoon appear higher than before noon.

Judging from these results, cloud coverage seems to have a large influence on the formaldehyde production (mainly methane oxidation), making 14 and 15 October the best examples for the (almost) cloud-free behavior and development of $\mathrm{HCHO}$ background concentration in the clean and remote marine environment. Precursor compounds from oceanic sources (DMS, methanol etc.) possibly contribute, especially to the HCHO maximum on 14 October, as mentioned above. Reported background concentrations from other stud- ies ranging from $0.2-1.0 \mathrm{ppbv}$ in remote marine environments (Singh et al., 2001; Weller et al., 2000) therefore agree with our results, although we found a maximum concentration of $>1 \mathrm{ppbv}$ in elevated altitudes under cloud-free conditions in the subtropical remote ocean (latitude $\approx 20^{\circ} \mathrm{N}$ ) at noontime on 14 October. Still et al. (2006) reported a similar diurnal cycle with enhanced levels of HCHO during the day, which are comparable to our results, in the remote marine boundary layer measured by gas chromatography at Mace Head, Ireland. In comparison, reported formaldehyde levels as derived from DOAS measurements in the same tropical region as TransBrom, but close to local sources of precursor species in a rain forest environment on Borneo, Malaysia (compare Fig. 11), reach up to 4.5 ppbv (MacDonald et al., 2012). These observations also show maximum concentrations around noon and in the afternoon, but the diurnal cycle and absolute values here are dominated by the emission and chemistry of precursor substances.

Due to the diurnal cycle found in formaldehyde vertical columns, care must be taken with respect to the comparison between MAX-DOAS and satellite measurements. Therefore, the vertical columns have been averaged between 09:00 and 11:00 LT as this corresponds roughly to the satellite overflight time. In addition, as mentioned above, satellite instruments have a much shorter light path through the troposphere than MAX-DOAS instruments, resulting in a poorer sensitivity for tropospheric absorbers. Thus, as a result of the small amount of HCHO (pure background signal, see Fig. 11), the MAX-DOAS vertical columns had to be compared with monthly averages seen from satellite (Fig. 17). Due to the poor coverage of SCIAMACHY in comparison with GOME-2, this comparison could be performed only for GOME-2 data.

Two examples of the influence of bad weather can be found in the data (Fig. 17): the minimum of $1 \times$ $10^{15} \mathrm{molec}^{-2}$ at $\approx 24^{\circ} \mathrm{N}$ in MAX-DOAS data results from the low formaldehyde columns on 13 October (compare Fig. 14 and Fig. 12) which are a consequence of washing out. A second example is the delay of MAX-DOAS data in comparison to GOME- 2 when increasing at $\approx 10^{\circ} \mathrm{S}$ which is most likely an effect of comparing point-in-time measurements with monthly averages: as rainy and cloudy conditions predominated during the cruise in the Coral sea (21-24 October, see Fig. 1), consequently, the MAX-DOAS measurements remain small, while GOME-2 values also average over periods with better weather and less clouds yielding higher formaldehyde concentrations.

As a consequence of the comparison of MAX-DOAS with monthly averages, the agreement of single maxima and minima cannot be expected. Apart from the effect of cloudy weather as discussed above, MAX-DOAS and GOME-2 data

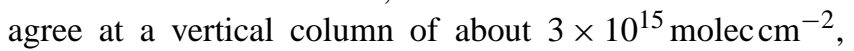
which can be considered as a typical value for the formaldehyde vertical column above the remote ocean for the time of the GOME-2 overflight. 

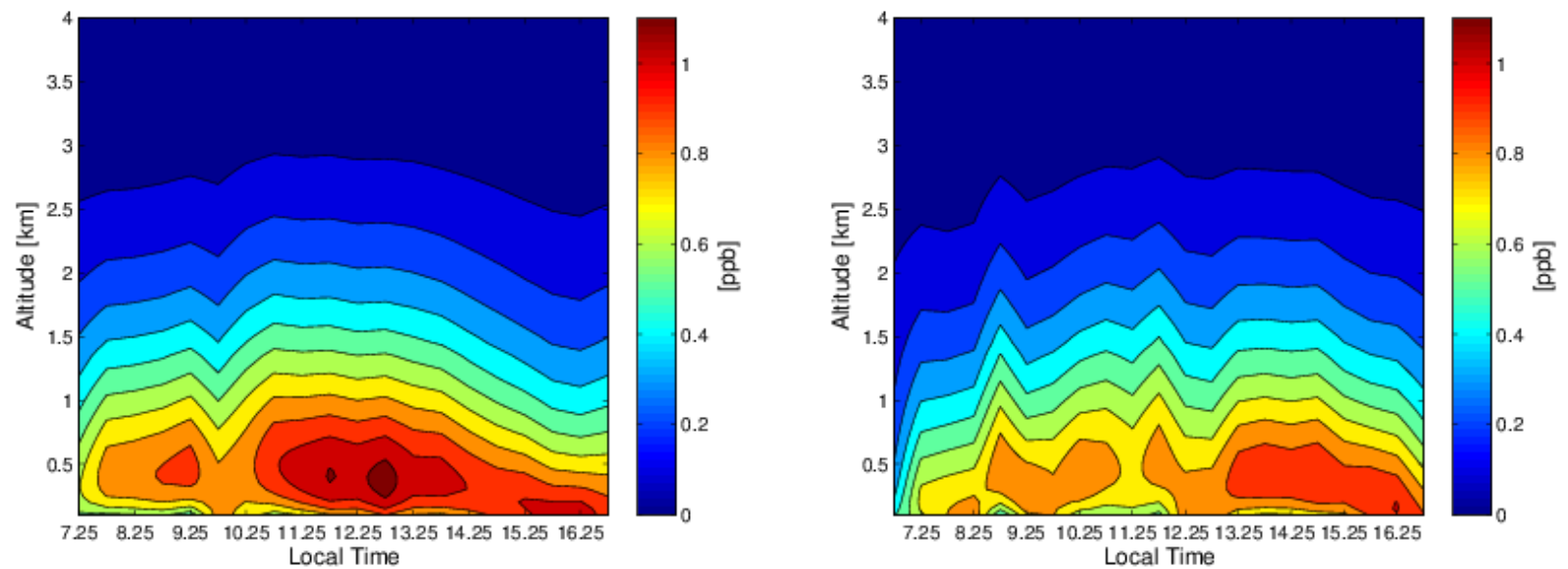

Fig. 15. Retrieved formaldehyde profiles for 14 October (left) and 15 October (right) having reasonable viewing conditions. The only completely cloud-free period of the cruise was on 14 October around noon, coinciding with maximum formaldehyde concentrations of $1.1 \mathrm{ppbv}$ in an altitude of $\approx 400 \mathrm{~m}$.
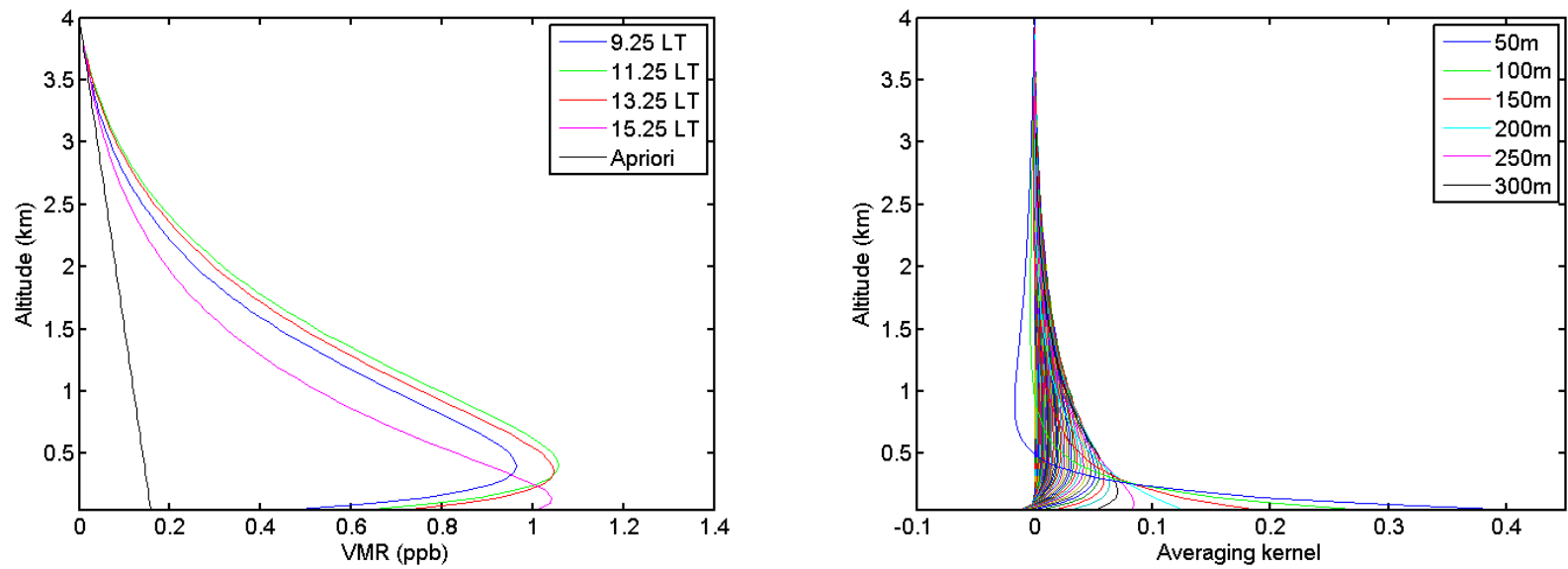

Fig. 16. LHS: example profiles of HCHO from 14 October 2009 (corresponding to Fig. 15, left). RHS: exemplarily averaging kernels of the retrieved profile on 14 October 2009, 09:25 LT (blue profile on left-hand side).

\section{Summary and conclusions}

During the shipborne field campaign TransBrom, MAXDOAS measurements of formaldehyde and (stratospheric and tropospheric) nitrogen dioxide were performed in the western Pacific. The objectives of this study were to retrieve background concentrations of these trace gases as well as validating measurements from the SCIAMACHY and GOME-2 satellite instruments.

For stratospheric $\mathrm{NO}_{2}$, a characteristic latitude-dependant $\mathrm{U}$-shaped behavior was found, which is reproduced by both satellite instruments (Fig. 4). $\mathrm{NO}_{2}$ morning values are lower than evening values due to slow photolysis of $\mathrm{N}_{2} \mathrm{O}_{5}$ during the course of the day. In low latitudes an increase of $8.7 \pm$ $0.5 \times 10^{13}$ molec cm $^{-2} \mathrm{~h}^{-1}$ was found. The SCIAMACHY and GOME- $2 \mathrm{NO}_{2}$ columns differ by only $\approx 1 \%$ from each other and by a value of $(0.45-0.68) \pm 1.3 \times 10^{14}$ molec cm $^{-2}$ from the MAX-DOAS morning values, which is a con- sequence of the satellite's overflight time (09:30 LT resp. 10:00 LT) and the stratospheric $\mathrm{NO}_{2}$ diurnal cycle (Fig. 5).

Over the remote ocean, significantly enhanced columns of tropospheric $\mathrm{NO}_{2}$ were found only in regions where higher ship traffic could be verified (i.e. crossing of shipping routes, see Figs. 6 and 1c). In the polluted marine environment close to Japan, $\mathrm{NO}_{2}$ events were observed with peak concentrations up to $0.8 \mathrm{ppbv}$ close to the ground, whereas the background concentration did not exceed $0.2 \mathrm{ppbv}$. When leaving the region influenced by the Japanese islands and the anthropogenic activities (shipping) connected to it, the tropospheric $\mathrm{NO}_{2}$ columns decreased below an estimated detection limit of $1.3 \times 10^{14}$ molec $\mathrm{cm}^{-2}$ (50 pptv) (see Fig. 8), which can therefore be considered an upper estimate for the tropospheric $\mathrm{NO}_{2}$ column in the clean air over the remote ocean. This estimated background concentration is lower than model values, suggesting $\approx 4 \times 10^{14} \mathrm{molec}^{-2}$ for 


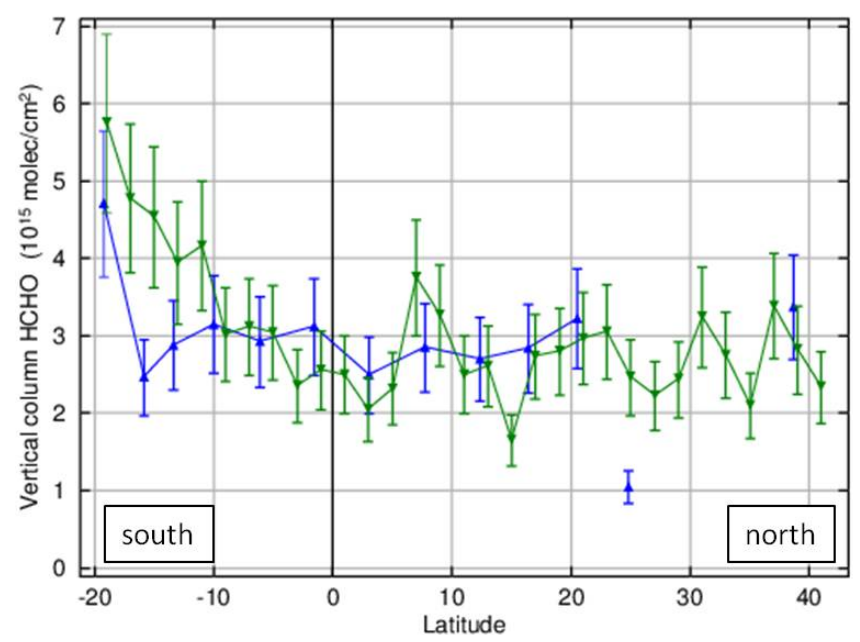

Fig. 17. Comparison between MAX-DOAS (blue) and GOME-2 (green) HCHO vertical columns as a function of latitude. MAXDOAS data was averaged between 09:00-11:00 LT (approx. time of GOME-2 overflight). The GOME-2 values are calculated from monthly average for October 2009 and binned to a $2^{\circ}$ grid for better visualization of the results.

the tropospheric $\mathrm{NO}_{2}$ column above the Pacific ocean between $180-210^{\circ}$ longitude (Hilboll et al., 2012). Close to the Japanese coast, averages of vertical columns from the satellite instruments are 2-3 times higher than corresponding MAX-DOAS vertical columns as a consequence of enhanced levels of $\mathrm{NO}_{2}$ over Japan. Over the remote ocean, the monthly average column from GOME-2 is in good agreement with the estimated $\mathrm{NO}_{2}$ background column derived from MAX-DOAS data (see above).

Profiles and vertical columns of formaldehyde (Fig. 14), which are considered to originate mainly from methane oxidation, show a characteristic diurnal cycle over the tropical and subtropical ocean (most apparent on almost cloud-free days) with maxima at noon in elevated altitudes (Fig. 15). This background formaldehyde concentration was found to be highly dependent on the cloud coverage, while no latitudinal dependence in the region $40^{\circ} \mathrm{N}$ to $20^{\circ} \mathrm{S}$ could be observed (Figs. 14 and 17). Maximum values for the vertical column on cloud-free occasions were found to be $\approx$ $4 \times 10^{15}$ molec cm $^{-2}$ corresponding to a peak concentration of $1.1 \mathrm{ppbv}$ (Figs. 14 and 15), which is slightly higher than earlier reported values ranging from $0.2-1$ ppbv (e.g., Weller et al., 2000; Singh et al., 2001; Burkert et al., 2001), but by far lower than maximum values of $4.5 \mathrm{ppbv}$ found by the DOAS technique in a tropical rain forest environment on Borneo, Malaysia (MacDonald et al., 2012). Furthermore, the maximum $\mathrm{HCHO}$ concentration of $1.1 \mathrm{ppbv}$ found above the open ocean on 14 October could be increased due to enhanced levels of precursor compounds other than methane (e.g., DMS, methanol) from oceanic sources. The diurnal cycle of $\mathrm{HCHO}$ is similar to earlier reported observa- tions from Still et al. (2006) in the remote marine boundary layer. In addition, a transport event of formaldehyde (or its precursors) was found $\approx 150 \mathrm{~km}$ away from the only possible source (island with rainforest vegetation) and calculated backward trajectories suggest that the formaldehyde or its precursors bridged this distance in $12-18 \mathrm{~h}$ before being detected by our MAX-DOAS instrument. The GOME-2 and MAX-DOAS measurements agree on typical values of $\approx 3 \times 10^{15} \mathrm{molec}^{-2}$ for the remote ocean at the overpass time.

Acknowledgements. We acknowledge the GEOMAR in Kiel, Germany, especially Kirstin Krüger and Birgit Quack for organizing the national WGL project TransBrom and the TransBromSONNE (BMBF) ship campaign. The ship measurements work for this paper were partly funded by the BMBF through grant 03G0731A. The contribution from University of Bremen was supported by the EU via the GEOMon Integrated Project (contract FP6-2005-Global-4-036677) and the SHIVA project (contract 226224-FP7-ENV-2008-1). The Bremen instrument was partly funded by the University of Bremen and the DLR trough the ENVIVAL-life project (50EE0839). Douglas Horton and his team from US Coast Guard Operations Systems Center provided ship position data from the Automated Mutual-Assistance Vessel Rescue System (AMVER). Backward trajectories were calculated with the HYSPLIT online tool from the National Oceanic and Atmospheric Administration (NOAA). For his helpful comments, many thanks also to Klaus Pfeilsticker from IUP Heidelberg.

Edited by: B. Quack

\section{References}

Anderson, L. G., Lanning, J. A., Barrell, R., Miyagishima, J., Jones, R. H., and Wolfe, P.: Sources and sinks of formaldehyde and acetaldehyde: an analysis of Denver's ambient concentration data, Atmos. Environ., 30, 2113-2123, 1996.

Arlander, D. W., Brüning, D., Schmidt, U., and Ehhalt, D. H.: The tropospheric distribution of formaldehyde during TROPOZ II, J. Atmos. Chem., 22, 251-268, 1995.

Bates, D. R. and Hays, P. B.: Atmospheric nitrous oxide, Planet. Space Sci., 15, 189-197, 1967.

Beirle, S., Platt, U., von Glasow, R., Wenig, M., and Wagner, T.: Estimate of nitrogen oxide emissions from shipping by satellite remote sensing, Geophys. Res. Lett., 31, L18102, doi:10.1029/2004GL020312, 2004.

Boersma, K. F., Eskes, H. J., and Brinksma, E. J.: Error analysis for tropospheric $\mathrm{NO}_{2}$ retrieval from space, J. Geophys. Res., 109, D04311, doi:10.1029/2003JD003962, 2004.

Bogumil, K., Orphal, J., Homann, T., Voigt, S., Spietz, P., Fleischmann, O. C., Vogel, A., Hartmann, M., Kromminga, H., Bovensmann, H., Frerick, J., and Burrows, J. P.: Measurements of molecular absorption spectra with the SCIAMACHY preflight model: instrument characterization and reference data for atmospheric remote-sensing in the $230-2380 \mathrm{~nm}$ region, J. Photochem. Photobiol. A, 157, 167-184, 2003. 
Bovensmann, H., Burrows, J. P., Buchwitz, M., Frerick, J., Noël, S., Rozanov, V. V., Chance, K. V., and Goede, A. P. H.: SCIAMACHY: mission objectives and measurement modes, J. Atmos. Sci., 56, 127-150, 1999.

Brasseur, G. P., Orlando, J. J., and Tyndall, G. S.: Atmospheric Chemistry and Global Change, Oxford University Press, New York, 1999.

Burkert, J., Andres-Hernandez, M. D., Stobener, D., Burrows, J. P., Weissenmayer, M., and Kraus, A.: Peroxy radical and related trace gas measurements in the boundary layer above the Atlantic Ocean, J. Geophys. Res.-Atmos., 106, 5457-5477, 2001.

Burrows, J. P., Hölzle, E., Goede, A. P. H., Visser, H., and Fricke, W.: SCIAMACHY - scanning imaging absorption spectrometer for atmospheric chartography, Acta Astronaut., 35, 445-451, 1995.

Burrows, J. P., Weber, M., Buchwitz, M., Rozanov, V., LadstatterWeissenmayer, A., Richter, A., DeBeek, R., Hoogen, R., Bramstedt, K., Eichmann, K. U., and Eisinger, M.: The global ozone monitoring experiment (GOME): mission concept and first scientific results, J. Atmos. Sci., 56, 151-175, 1999.

Callies, J., Corpaccioli, E., Eisinger, M., Hahne, A., and Lefebvre, A.: GOME-2 - Metop's second-generation sensor for operational ozone monitoring, Esa Bull.-Eur. Space, 102, 28-36, 2000.

Crutzen, P. J.: The influence of nitrogen oxides on the atmospheric ozone content, Q. J. Roy. Meteor. Soc., 96, 320-325, 1970.

De Smedt, I., Müller, J.-F., Stavrakou, T., van der A, R., Eskes, H., and Van Roozendael, M.: Twelve years of global observations of formaldehyde in the troposphere using GOME and SCIAMACHY sensors, Atmos. Chem. Phys., 8, 4947-4963, doi:10.5194/acp-8-4947-2008, 2008.

Draxler, R. R. and Rolph, G. D.: HYSPLIT (HYbrid SingleParticle Lagrangian Integrated Trajectory) model access via NOAA ARL READY website, available at: http://ready.arl.noaa. gov/HYSPLIT.php, last access: September 2011.

Fleischmann, O. C., Hartmann, M., Burrows, J. P., and Orphal, J.: New ultraviolet absorption cross-sections of $\mathrm{BrO}$ at atmospheric temperatures measured by time-windowing Fourier transform spectroscopy, J. Photochem. Photobiol. A, 168, 117-132, 2004.

Franke, K., Richter, A., Bovensmann, H., Eyring, V., Jöckel, P., Hoor, P., and Burrows, J. P.: Ship emitted $\mathrm{NO}_{2}$ in the Indian Ocean: comparison of model results with satellite data, Atmos. Chem. Phys., 9, 7289-7301, doi:10.5194/acp-9-7289-2009, 2009.

Frieß, U., Sihler, H., Sander, R., Pöhler, D., Yilmaz, S., and Platt, U.: The vertical distribution of $\mathrm{BrO}$ and aerosols in the Arctic: measurements by active and passive differential optical absorption spectroscopy, J. Geophys. Res., 116, D00R04, doi:10.1029/2011JD015938, 2011.

Gil, M., Yela, M., Gunn, L. N., Richter, A., Alonso, I., Chipperfield, M. P., Cuevas, E., Iglesias, J., Navarro, M., Puentedura, O., and Rodríguez, $\mathrm{S}$.: $\mathrm{NO}_{2}$ climatology in the northern subtropical region: diurnal, seasonal and interannual variability, Atmos. Chem. Phys., 8, 1635-1648, doi:10.5194/acp-8-1635-2008, 2008.

Großmann, K., Frieß, U., Peters, E., Wittrock, F., Lampel, J., Yilmaz, S., Tschritter, J., Sommariva, R., von Glasow, R., Quack, B., Krüger, K., Pfeilsticker, K., and Platt, U.: Iodine monoxide in the Western Pacific marine boundary layer, Atmos. Chem. Phys. Discuss., 12, 27475-27519, doi:10.5194/acpd-12-27475-
2012, 2012.

Heckel, A., Richter, A., Tarsu, T., Wittrock, F., Hak, C., Pundt, I., Junkermann, W., and Burrows, J. P.: MAX-DOAS measurements of formaldehyde in the Po-Valley, Atmos. Chem. Phys., 5, 909 918, doi:10.5194/acp-5-909-2005, 2005.

Hendrick, F., Van Roozendael, M., Kylling, A., Petritoli, A., Rozanov, A., Sanghavi, S., Schofield, R., von Friedeburg, C., Wagner, T., Wittrock, F., Fonteyn, D., and De Mazière, M.: Intercomparison exercise between different radiative transfer models used for the interpretation of ground-based zenith-sky and multi-axis DOAS observations, Atmos. Chem. Phys., 6, 93-108, doi:10.5194/acp-6-93-2006, 2006.

Hilboll, A., Richter, A., Rozanov, A., Hodnebrog, Ø., Heckel, A., Solberg, S., Stordal, F., and Burrows, J. P.: Retrieval of tropospheric $\mathrm{NO}_{2}$ columns from SCIAMACHY combining measurements from limb and nadir geometries, Atmos. Meas. Tech. Discuss., 5, 5043-5105, doi:10.5194/amtd-5-5043-2012, 2012.

Hönninger, G., von Friedeburg, C., and Platt, U.: Multi axis differential optical absorption spectroscopy (MAX-DOAS), Atmos. Chem. Phys., 4, 231-254, doi:10.5194/acp-4-231-2004, 2004.

Irie, H., Kanaya, Y., Akimoto, H., Tanimoto, H., Wang, Z., Gleason, J. F., and Bucsela, E. J.: Validation of OMI tropospheric $\mathrm{NO}_{2}$ column data using MAX-DOAS measurements deep inside the North China Plain in June 2006: Mount Tai Experiment 2006, Atmos. Chem. Phys., 8, 6577-6586, doi:10.5194/acp-86577-2008, 2008.

Johnston, H.: Reduction of stratospheric ozone by nitrogen oxide catalysts from supersonic transport exhaust, Science, 173, 517$522,1971$.

Konovalov, I. B., Beekmann, M., Richter, A., Burrows, J. P., and Hilboll, A.: Multi-annual changes of $\mathrm{NO}_{\mathrm{x}}$ emissions in megacity regions: nonlinear trend analysis of satellite measurement based estimates, Atmos. Chem. Phys., 10, 8481-8498, doi:10.5194/acp-10-8481-2010, 2010.

Kreher, K., Fiedler, M., Gomer, T., Stutz, J., and Platt, U.: The latitudinal distribution $\left(50^{\circ} \mathrm{N}-50^{\circ} \mathrm{S}\right)$ of $\mathrm{NO}_{2}$ and $\mathrm{O}_{3}$ in October/November 1990, Geophys. Res. Lett., 22, 1217-1220, 1995.

Krüger, K. and Quack, B.: Introduction to special issue: the TransBrom Sonne expedition in the tropical West Pacific, Atmos. Chem. Phys. Discuss., 12, 1401-1418, doi:10.5194/acpd-121401-2012, 2012.

Lee, D. S., Köhler, I., Grobler, E., Rohrer, F., Sausen, R., GallardoKlenner, L., Olivier, J. G. J., Dentener, F. J., and Bouwman, A. F.: Estimations of global $\mathrm{NO}_{\mathrm{x}}$ emissions and their uncertainties, Atmos. Environ., 31, 1735-1749, 1997.

Leue, C., Wenig, M., Wagner, T., Klimm, O., Platt, U., and Jahne, B.: Quantitative analysis of $\mathrm{NO}_{\mathrm{x}}$ emissions from global Ozone Monitoring Experiment satellite image sequences, J. Geophys. Res.-Atmos., 106, 5493-5505, 2001.

MacDonald, S. M., Oetjen, H., Mahajan, A. S., Whalley, L. K., Edwards, P. M., Heard, D. E., Jones, C. E., and Plane, J. M. C.: DOAS measurements of formaldehyde and glyoxal above a south-east Asian tropical rainforest, Atmos. Chem. Phys., 12, 5949-5962, doi:10.5194/acp-12-5949-2012, 2012.

Marbach, T., Beirle, S., Platt, U., Hoor, P., Wittrock, F., Richter, A., Vrekoussis, M., Grzegorski, M., Burrows, J. P., and Wagner, T.: Satellite measurements of formaldehyde linked to shipping emissions, Atmos. Chem. Phys., 9, 8223-8234, doi:10.5194/acp-98223-2009, 2009. 
Martin, M., Pöhler, D., Seitz, K., Sinreich, R., and Platt, U.: BrO measurements over the Eastern North-Atlantic, Atmos. Chem. Phys., 9, 9545-9554, doi:10.5194/acp-9-9545-2009, 2009.

Martin, R. V., Chance, K., Jacob, D. J., Kurosu, T. P., Spurr, R. J. D., Bucsela, E., Gleason, J. F., Palmer, P. I., Bey, I., Fiore, A. M., Li, Q. B., Yantosca, R. M., and Koelemeijer, R. B. A.: An improved retrieval of tropospheric nitrogen dioxide from GOME, J. Geophys. Res.-Atmos., 107, 4437, doi:10.1029/2001JD001027, 2002.

Meller, R. and Moortgat, G. K.: Temperature dependence of the absorption cross sections of formaldehyde between 223 and $323 \mathrm{~K}$ in the wavelength range $225-375 \mathrm{~nm}$, J. Geophys. Res., 105, 7089-7101, 2000.

Palmer, P. I., Jacob, D. J., Fiore, A. M., Martin, R. V., Chance, K., and Kurosu, T. P.: Mapping isoprene emissions over North America using formaldehyde column observations from space, $\mathrm{J}$. Geophys. Res.-Atmos., 108, 4180, doi:10.1029/2002JD002153, 2003.

Pinardi, G., Van Roozendael, M., Abuhassan, N., Adams, C., Cede, A., Clémer, K., Fayt, C., Frieß, U., Gil, M., Herman, J., Hermans, C., Hendrick, F., Irie, H., Merlaud, A., Navarro Comas, M., Peters, E., Piters, A. J. M., Puentedura, O., Richter, A., Schönhardt, A., Shaiganfar, R., Spinei, E., Strong, K., Takashima, H., Vrekoussis, M., Wagner, T., Wittrock, F., and Yilmaz, S.: MAXDOAS formaldehyde slant column measurements during CINDI: intercomparison and analysis improvement, Atmos. Meas. Tech. Discuss., 5, 6679-6732, doi:10.5194/amtd-5-6679-2012, 2012.

Piters, A. J. M., Boersma, K. F., Kroon, M., Hains, J. C., Van Roozendael, M., Wittrock, F., Abuhassan, N., Adams, C., Akrami, M., Allaart, M. A. F., Apituley, A., Beirle, S., Bergwerff, J. B., Berkhout, A. J. C., Brunner, D., Cede, A., Chong, J., Clémer, K., Fayt, C., Frieß, U., Gast, L. F. L., GilOjeda, M., Goutail, F., Graves, R., Griesfeller, A., Großmann, K., Hemerijckx, G., Hendrick, F., Henzing, B., Herman, J., Hermans, C., Hoexum, M., van der Hoff, G. R., Irie, H., Johnston, P. V., Kanaya, Y., Kim, Y. J., Klein Baltink, H., Kreher, K., de Leeuw, G., Leigh, R., Merlaud, A., Moerman, M. M., Monks, P. S., Mount, G. H., Navarro-Comas, M., Oetjen, H., Pazmino, A., Perez-Camacho, M., Peters, E., du Piesanie, A., Pinardi, G., Puentedura, O., Richter, A., Roscoe, H. K., Schönhardt, A., Schwarzenbach, B., Shaiganfar, R., Sluis, W., Spinei, E., Stolk, A. P., Strong, K., Swart, D. P. J., Takashima, H., Vlemmix, T., Vrekoussis, M., Wagner, T., Whyte, C., Wilson, K. M., Yela, M., Yilmaz, S., Zieger, P., and Zhou, Y.: The Cabauw Intercomparison campaign for Nitrogen Dioxide measuring Instruments (CINDI): design, execution, and early results, Atmos. Meas. Tech., 5, 457-485, doi:10.5194/amt-5-457-2012, 2012.

Platt, U.: Differential optical absorption spectroscopy (DOAS), Chem. Anal. Series, 127, 27-83, 1994.

Platt, U. and Stutz, J.: Differential Optical Absorption Spectroscopy: Principles and Applications, Physics of Earth and Space Environments, Springer Verlag, Berlin Heidelberg, 2008.

Quack, B.: Cruise Report TransBrom SONNE, Tech. rep., IFM Geomar, Kiel, Germany, 2010.

Raymond, C. and Baker, K. S.: Optical properties of the clearest natural waters, Appl. Optics, 20, 177-184, 1981.

Richter, A.: Absorptionsspektroskopische Messungen stratosphärischer Spurengase über Bremen, $53^{\circ} \mathrm{N}, \mathrm{Ph} . \mathrm{D}$. thesis, University of Bremen, Bremen, Germany, 1997.

Richter, A. and Burrows, J. P.: Tropospheric $\mathrm{NO}_{2}$ frome GOME Measurements, Adv. Space Res., 29, 1673-1683, 2002.

Richter, A., Eyring, V., Burrows, J. P., Bovensmann, H., Lauer, A., Sierk, B., and Crutzen, P. J.: Satellite measurements of $\mathrm{NO}_{2}$ from international shipping emissions, Geophys. Res. Lett., 31, L23110, doi:10.1029/2004GL020822, 2004.

Richter, A., Burrows, J. P., Nüß, H., Granier, C., and Niemeier, U.: Increase in tropospheric nitrogen dioxide over China observed from space, Nature, 437, 129-132, 2005.

Richter, A., Begoin, M., Hilboll, A., and Burrows, J. P.: An improved $\mathrm{NO}_{2}$ retrieval for the GOME-2 satellite instrument, Atmos. Meas. Tech., 4, 1147-1159, doi:10.5194/amt-4-1147-2011, 2011.

Rodgers, C. D.: Inverse Methods for Atmospheric Sounding - Theory and Practice, Series on Atmospheric, Oceanic and Planetary Physics, World Scientific, Singapore, 2000.

Rolph, G. D.: Real-time Environmental Applications and Display sYstem (READY) Website, available at: http://ready.arl.noaa. gov, last access: September 2011.

Roscoe, H. K., Van Roozendael, M., Fayt, C., du Piesanie, A., Abuhassan, N., Adams, C., Akrami, M., Cede, A., Chong, J., Clémer, K., Friess, U., Gil Ojeda, M., Goutail, F., Graves, R., Griesfeller, A., Grossmann, K., Hemerijckx, G., Hendrick, F., Herman, J., Hermans, C., Irie, H., Johnston, P. V., Kanaya, Y., Kreher, K., Leigh, R., Merlaud, A., Mount, G. H., Navarro, M., Oetjen, H., Pazmino, A., Perez-Camacho, M., Peters, E., Pinardi, G., Puentedura, O., Richter, A., Schönhardt, A., Shaiganfar, R., Spinei, E., Strong, K., Takashima, H., Vlemmix, T., Vrekoussis, M., Wagner, T., Wittrock, F., Yela, M., Yilmaz, S., Boersma, F., Hains, J., Kroon, M., Piters, A., and Kim, Y. J.: Intercomparison of slant column measurements of $\mathrm{NO}_{2}$ and $\mathrm{O}_{4}$ by MAX-DOAS and zenith-sky UV and visible spectrometers, Atmos. Meas. Tech., 3, 1629-1646, doi:10.5194/amt-3-1629-2010, 2010.

Rozanov, A., Rozanov, V., Buchwitz, M., Kokhanovsky, A., and Burrows, J. P.: SCIATRAN 2.0 - a new radiative transfer model for geophysical applications in the $175-2400 \mathrm{~nm}$ spectral region, Adv. Space Res., 36, 1015-1019, 2005.

Seco, R., Peñuelas, J., and Filella, I.: Short-chain oxygenated VOCs: emission and uptake by plants and atmospheric sources, sinks, and concentrations, Atmos. Environ., 41, 2477-2499, 2006.

Singh, H., Chen, Y., Staudt, A., Jacob, D., Blake, D., Heikes, B., and Snow, J.: Evidence from the Pacific troposphere for large global sources of oxygenated organic compounds, Nature, 410, 1078-1081, 2001.

Sinreich, R., Coburn, S., Dix, B., and Volkamer, R.: Ship-based detection of glyoxal over the remote tropical Pacific Ocean, Atmos. Chem. Phys., 10, 11359-11371, doi:10.5194/acp-1011359-2010, 2010.

Stavrakou, T., Müller, J.-F., De Smedt, I., Van Roozendael, M., van der Werf, G. R., Giglio, L., and Guenther, A.: Global emissions of non-methane hydrocarbons deduced from SCIAMACHY formaldehyde columns through 2003-2006, Atmos. Chem. Phys., 9, 3663-3679, doi:10.5194/acp-9-3663-2009, 2009.

Still, T. J., Al-Haider, S., Seakins, P. W., Sommariva, R., Stanton, J. C., Mills, G., and Penkett, S. A.: Ambient formaldehyde 
measurements made at a remote marine boundary layer site during the NAMBLEX campaign - a comparison of data from chromatographic and modified Hantzsch techniques, Atmos. Chem. Phys., 6, 2711-2726, doi:10.5194/acp-6-2711-2006, 2006.

Takashima, H., Irie, H., Kanaya, Y., and Syamsudin, F.: $\mathrm{NO}_{2}$ observations over the Western Pacific and Indian Ocean by MAXDOAS on Kaiyo, a Japanese research vessel, Atmos. Meas. Tech. Discuss., 4, 6069-6095, doi:10.5194/amtd-4-6069-2011, 2011.

Vandaele, A. C., Hermans, C., Simon, P. C., Roozendael, M. V., Guilmot, J. M., Carleer, M., and Colin, R.: Fourier transform measurement of $\mathrm{NO}_{2}$ absorption cross-section in the visible range at room temperature, J. Atmos. Chem., 25, 289-305, 1996.

Vountas, M., Rozanov, V. V., and Burrows, J. P.: Ring effect: impact of rotational Raman scattering on radiative transfer in Earth's atmosphere, J. Quant. Spectrosc. Ra., 60, 943-961, 1998.

Vountas, M., Richter, A., Wittrock, F., and Burrows, J. P.: Inelastic scattering in ocean water and its impact on trace gas retrievals from satellite data, Atmos. Chem. Phys., 3, 1365-1375, doi:10.5194/acp-3-1365-2003, 2003.

Vrekoussis, M., Wittrock, F., Richter, A., and Burrows, J. P.: GOME-2 observations of oxygenated VOCs: what can we learn from the ratio glyoxal to formaldehyde on a global scale?, Atmos. Chem. Phys., 10, 10145-10160, doi:10.5194/acp-1010145-2010, 2010.

Wagner, T., Beirle, S., Brauers, T., Deutschmann, T., Frieß, U., Hak, C., Halla, J. D., Heue, K. P., Junkermann, W., Li, X., Platt, U., and Pundt-Gruber, I.: Inversion of tropospheric profiles of aerosol extinction and $\mathrm{HCHO}$ and $\mathrm{NO}_{2}$ mixing ratios from MAX-DOAS observations in Milano during the summer of 2003 and comparison with independent data sets, Atmos. Meas. Tech., 4, 2685-2715, doi:10.5194/amt-4-2685-2011, 2011.

Wang, P., Stammes, P., van der A, R., Pinardi, G., and van Roozendael, M.: FRESCO+: an improved $\mathrm{O}_{2}$ A-band cloud retrieval algorithm for tropospheric trace gas retrievals, Atmos. Chem. Phys., 8, 6565-6576, doi:10.5194/acp-8-6565-2008, 2008.
Weller, R., Schrems, O., Boddenberg, A., Gäb, S., and Gautrois, M.: Meridional distribution of hydroperoxides and formaldehyde in the marine boundary layer of the Atlantic $\left(48^{\circ} \mathrm{N}-35^{\circ} \mathrm{S}\right)$ measured during the Albatross campaign, J. Geophys. Res., 105, 14401-14412, 2000.

Wittrock, F.: The retrieval of oxygenated volatile organic compounds by remote sensing techniques, Ph.D., University of Bremen, Bremen, Germany, available at: http://www.doas-bremen. de/paper/diss_wittrock_06.pdf (last access: April 2012), 2006.

Wittrock, F., Richter, A., Ladstätter-Weißenmayer, A., and Burrows, J. P.: Global Observations of Formaldehyde, Proceedings of the ERS-ENVISAT Symposium, ESA Publication SP-461, ESRIN, the ESA centre for Earth Observation, Frascati, 2000.

Wittrock, F., Oetjen, H., Richter, A., Fietkau, S., Medeke, T., Rozanov, A., and Burrows, J. P.: MAX-DOAS measurements of atmospheric trace gases in Ny-Ålesund - Radiative transfer studies and their application, Atmos. Chem. Phys., 4, 955-966, doi:10.5194/acp-4-955-2004, 2004.

Wittrock, F., Richter, A., Oetjen, H., Burrows, J. P., Kanakidou, M., Myriokefalitakis, S., Volkamer, R., Beirle, S., Platt, U., and Wagner, T.: Simultaneous global observations of glyoxal and formaldehyde from space, Geophys. Res. Lett., 33, L16804, doi:10.1029/2006GL026310, 2006.

Wittrock, F., Clémer, K., Beirle, S., Berkhout, S., Brunner, D., Friess, U., Hay, T., Irie, H., Kreher, K., Oetjen, H., Peters, E., Piters, A., Richter, A., Van Roozendael, M., Sluis, W., Spinei, E., and Wagner, T.: Measurements of $\mathrm{NO}_{2}$ profiles with MAXDOAS: Theoretical and practical case studies as part of the Cabauw Intercomparison campaign for Nitrogen Dioxide Measuring Instruments (CINDI), Atmos. Meas. Tech. Discuss., in preparation, 2012. 